\title{
Zło konieczne, substytut, szansa - wykorzystanie komunikatora Skype w badaniach jakościowych
}

\author{
Izabela Ślęzak \\ Uniwersytet Łódzki
}

DOI: https://doi.org/10.18778/1733-8069.17.4.05

\begin{abstract}
Słowa kluczowe: wywiad jakościowy zapośredniczony przez Skype'a, wywiad online, wywiad realizowany poprzez wideokonferencję, wywiad swobodny, Internet

Abstrakt: Celem artykułu jest omówienie techniki wywiadów swobodnych online w szczególnej formie wywiadów prowadzonych za pośrednictwem komunikatora Skype. Choć są one coraz częściej wykorzystywane w badaniach jakościowych, budzą u badaczy mieszane reakcje - od postrzegania ich jako szansy, (nie)pełnowartościowego zamiennika wywiadu twarzą w twarz, po wręcz zagrożenie dla jakości badań. Na podstawie literatury przedmiotu w artykule omówione zostaną cechy wywiadu za pośrednictwem Skype’a, jego zalety i ograniczenia tak z perspektywy badacza, jak i uczestników badania. Przedstawione zostaną także wyniki porównań wywiadów online z tradycyjnymi, których dokonali badacze wykorzystujący w swoich projektach obie te techniki. W bardziej szczegółowy sposób omówiona zostanie kwestia relacji badacza z rozmówcą oraz dylematy etyczne związane z realizowaniem wywiadów zapośredniczonych przez Skype'a. Wskazane zostaną także warunki, kiedy tego rodzaju wywiad może być szczególnie przydatny.
\end{abstract}

Izabela Ślęzak, dr, zatrudniona na stanowisku adiunkta w Katedrze Socjologii Organizacji i Zarządzania Instytutu Socjologii Uniwersytetu Łódzkiego. Główne obszary zainteresowań naukowych to jakościowe metody badań społecznych, symboliczny interakcjonizm, socjologia pracy i pracy seksualnej.

\section{Adres kontaktowy:}

Katedra Socjologii Organizacji i Zarządzania

Instytut Socjologii, Wydział Ekonomiczno-Socjologiczny Uniwersytet Łódzki

ul. Rewolucji 1905r. nr 41/43, 90-214 Łódź

e-mail: izabela.slezak@uni.lodz.pl zauważa Piotr Siuda
(2016a), rozwój metod ba-
dawczych w naukach
społecznych jest ściśle chodzącymi we współczesnych społeczeństwach. Jako przykład podaje on techniki sondażowe, których rozwój przyspieszył dzięki zastosowaniu komputerów z coraz bardziej zaawansowanym oprogramowaniem do analizy danych. Z kolei rozkwit prasy, radia i telewizji sprzyjał rozwojowi metod analizy treści. Na sposób prowadzenia wywiadów swobodnych i wzrost ich popularno- 
ści wpłynął zaś łatwiejszy dostęp do różnych technologii rejestracji dźwięku. Wreszcie, powstanie i upowszechnienie się Internetu skłoniło badaczy do adaptowania konwencjonalnych technik do nowego środowiska (np. ankieta internetowa, netnografia) oraz tworzenia nowych sposobów gromadzenia danych (Jemielniak 2013; 2019; Siuda 2016b). Jednym z kierunków tej ewolucji jest wykorzystanie komunikacji elektronicznej do prowadzenia wywiadów jakościowych.

Choć może się wydawać, że temat ten nabrał znaczenia dopiero w kontekście pandemii COVID-19, już w latach 90. XX wieku badacze zainicjowali dyskusje nad wykorzystaniem technik komunikowania się (w tamtym czasie jedynie) głosowego w badaniach online (Deakin, Wakefield 2014). Spory te dotyczyły przede wszystkim możliwości i ograniczeń takiego sposobu prowadzenia wywiadów (Walther 1996 za Deakin, Wakefield 2014), co było pochodną szerszych dyskusji toczonych nad statusem komunikacji zapośredniczonej przez technologie, zwłaszcza Internet. Trudno bowiem nie zauważyć, że to, jak ludzie komunikują się ze sobą, zmieniło się znacząco w ostatnich dekadach. Do najważniejszych zmian należą: używanie w codziennych interakcjach (tak w życiu zawodowym, jak i prywatnym) różnych urządzeń (komputerów, i-padów, smartfonów), a także powszechne wykorzystywanie e-maili, wiadomości SMS i MMS, dzielenie się zdjęciami i nagraniami (Beneito-Montagut 2011; Weller 2015; Adams-Hutcheson, Longhurst 2017). Życie społeczne toczy się także w Internecie, co dla wielu ludzi jest tak oczywiste, że już niemal niezauważalne. W rezultacie granice między komunikacją online i offline stały się zamazane, a oba rodzaje komunikacji nierzadko przeplatają się w codziennym doświadczeniu (Beneito-Montagut 2011).
Wraz z postępem technologicznym, coraz tańszymi i powszechniej dostępnymi technologiami umożliwiającymi komunikowanie się na odległość stopniowo zyskały na popularności (choć raczej w badaniach ilościowych) wywiady za pośrednictwem telefonu, a następnie Internetu (Bertrand, Bourdeau 2010; Szpunar 2010; Stachura 2016; Jemielniak 2019). Dużą zmianą technologiczną, która wpłynęła na wzrost zainteresowania badaczy jakościowych wywiadami online, była możliwość wykorzystania wideokonferencji, a więc komunikowania się w czasie rzeczywistym, nie tylko za pomocą audio, ale i wideo (Sullivan 2012), a także wzrost dostępności Internetu szerokopasmowego (Weller 2015; Lo Iacono, Symonds, Brown 2016). Wielu badaczy już u progu drugiej dekady XXI w. widziało duży potencjał w stosowaniu wideokonferencji jako platformy do prowadzenia badań (Glassmeyer, Dibbs 2012), co przekładało się na publikacje naukowe poświęcone temu, w jaki sposób może zostać wykorzystane konkretne oprogramowanie, na przykład Skype (Hanna 2012; Weinmann i in. 2012; Deakin, Wakefield 2014).

Do głównych zalet podkreślanych przez zwolenników wywiadów za pośrednictwem Skype’a (czy innych komunikatorów, np. Zoom, Webex, GoToMeeting, Microsoft Teams) należy to, że (przy włączonej kamerze) umożliwiają one uzyskanie efektu podobnego do wywiadu twarzą w twarz, choć badacz i badani nie dzielą tej samej przestrzeni fizycznej (Sullivan 2012; Foley 2021). Co więcej, dzięki dystansowi przestrzennemu rozmówcy mogą czuć się bardziej anonimowo, komfortowo i bezpiecznie, a w rezultacie być bardziej otwarci podczas rozmowy (Batorski, Olcoń-Kubicka 2006; Meho 2006). Nie bez znaczenia jest też to, że wywiady online pozwalają obniżyć koszty badań. O tym, że technika ta nie sprawia w praktyce większych trudno- 
ści, może świadczyć fakt, że wielu stosujących ją badaczy $\mathrm{w}$ swoich raportach nie opisuje żadnych problemów związanych z jej użyciem lub też zaznacza, że wywiady nie odbiegały przebiegiem od tradycyjnych. Warto także zauważyć, że w projektach badawczych, w których pozostawiono rozmówcom wybór, w jaki sposób chcieliby udzielić wywiadu, część z nich preferowała wywiad za pośrednictwem Skype'a jako rozwiązanie bardziej komfortowe niż tradycyjne wywiady twarzą w twarz (Jenkins 2010; Hanna 2012; Deakin, Wakefield 2014; Adams-Hutcheson, Longhurst 2017; Whale 2017; Jenner, Myers 2019).

Niezależnie od rosnącego zainteresowania wywiadami online złotym standardem $\mathrm{w}$ badaniach jakościowych pozostają wywiady twarzą w twarz, prowadzone $\mathrm{w}$ bezpośrednim kontakcie $\mathrm{z}$ rozmówcami (Deakin, Wakefield 2014; Weller 2015; Jenner, Myers 2019; Krouwel, Jolly, Greenfield 2019). Zwykle pozostają one pierwszym wyborem badaczy, niezależnie od tego, że i z ich stosowaniem mogą wiązać się różnego rodzaju trudności. Wywiady online realizowane są dopiero wtedy, jeśli spotkanie twarzą w twarz nie jest możliwe (Deakin, Wakefield 2014), na przykład ze względu na odległość (Grochalska 2017), nagłą zmianę planów rozmówcy (Bielska, Kurek-Ochmańska, Łuczaj 2021), obostrzenia związane z pandemią COVID-19 (Krauz 2020). Rzadko przedstawia się wywiady zapośredniczone przez Internet jako świadomy wybór najlepszej zdaniem badacza techniki gromadzenia danych w konkretnym projekcie (np. Stojkow, Żuchowska 2014).

Głównym powodem rezerwy badaczy wobec wywiadów online są obawy, że komunikacja zapośredniczona przez technologię jest uboższa interakcyjnie niż komunikacja bezpośrednia, a bezosobowość i zdystansowanie nie sprzyjają nawiązaniu głębszej relacji z uczestnikami badań (Batorski, Olcoń-Kubicka 2006; Stachura 2016). Obawy dotyczą więc jakości danych zgromadzonych za pomocą tej techniki.

Pandemia COVID-19 przyczyniła się do jeszcze większej polaryzacji stanowisk wobec wywiadów online. W obliczu obostrzeń związanych z ograniczaniem kontaktów społecznych (szczególnie wiosną 2020 r., ale i podczas kolejnych lockdownów) oraz zmian $\mathrm{w}$ funkcjonowaniu instytucji bezpośrednie spotkania z rozmówcami stały się niemożliwe lub ryzykowne z punktu widzenia zdrowia badacza i badanych. Nie bez znaczenia były także zmiany społeczne wywołane przez pandemię. Uczestnicy badań i badacze doświadczali stresu i niepewności, musieli odnaleźć się w sytuacji zmiany priorytetów i codziennej rutyny, zdalnej pracy iedukacji, izolacji społecznej (Nind, Coverdale, Meckin 2021). Badacze, którzy planowali przeprowadzenie w tym okresie wywiadów jakościowych, stanęli przed dylematem, czy, a jeśli tak, to w jaki sposób, je zrealizować (Dyskusja... 2020). Niektórzy badacze wywiady za pośrednictwem Internetu postrzegali jako substytut tradycyjnych wywiadów i sposób na przystosowanie się do warunków pandemii (Foley 2021). Jednak inni obawiali się, że są skazani na technikę, która z założenia nie może przynieść wysokiej jakości danych (zob. Dyskusja... 2020; Polskie Towarzystwo Historii Mówionej 2020; Morgan i in. 2021).

Wobec rozbieżnych (czy wręcz sprzecznych) ocen wywiadów online chciałabym w niniejszym artykule odpowiedzieć na pytania: kiedy warto je zastosować? Jakie są korzyści z prowadzenia wywiadu za pośrednictwem Skype'a dla badacza i dla uczestników? Na jakie ryzyka powinien przygotować się badacz, który chciałby w ten sposób gromadzić dane? Odpowiadając na te pytania, odwołam się do badań przeprowadzonych z użyciem tej techniki i do pu- 
blikacji, które szczegółowo omawiają praktykę jej stosowania. Moim celem nie jest przedstawienie wywiadów swobodnych za pośrednictwem komunikatora Skype jako następcy tradycyjnych wywiadów twarzą w twarz ani ich (lepszej czy gorszej jakości) zamiennika. Chcę przybliżyć tę technikę jako kolejne, dostępne badaczom narzędzie, które ma co prawda swoje ograniczenia (tak jak każde inne narzędzie), ale może być efektywnie wykorzystywane w badaniach i przynieść dobre rezultaty.

Artykuł ten dotyczy wywiadów realizowanych przez Skype'a, ale omówione kwestie odnoszą się także do innych komunikatorów, za pomocą których można przeprowadzić wywiad audio i wideo (Brown 2018; Archibald i in. 2019). Skoncentrowałam się na Skypie, ponieważ był ${ }^{1}$ on często stosowany przez badaczy realizujących wywiady indywidualne, grupowe, fokusowe (Sullivan 2012) i cieszył się większym uznaniem niż inne dostępne programy (Deakin, Wakefield 2014; Lobe 2017; Lobe, Morgan, Hoffman 2020). W kolejnej sekcji wyjaśnię, z czego wynikała popularność Skype'a wśród badaczy i uczestników badań. Następnie omówię główne zalety i ryzyka, jakie wiążą się z jego stosowaniem w badaniach jakościowych. Więcej uwagi poświęcę zagadnieniu budowania relacji badacz-badany podczas interakcji online, a także kwestiom etycznym. Na koniec przytoczę wyniki porównań wywiadów online i tradycyjnych, prowadzonych przez badaczy stosujących obie te techniki w jednym projekcie badawczym.

\footnotetext{
${ }^{1}$ Używam czasu przeszłego, ponieważ wymuszone pandemią COVID-19 przejście do zdalnej pracy i edukacji spowodowało bardzo dynamiczny rozwój oprogramowania do prowadzenia wideokonferencji. Instytucje (uczelnie, instytuty badawcze, ale i szkoły czy miejsca pracy) często narzucały obowiązek stosowania (a więc i opanowania) konkretnego programu. Być może więc preferencje badaczy i potencjalnych uczestników badań uległy zmianie.
}

\section{Dlaczego Skype jest stosowany w badaniach jakościowych?}

Skype powstał w 2003 roku i bardzo szybko zyskał popularność wśród użytkowników². Cechuje się intuicyjną instalacją i obsługą (Given, Saumure 2015), umożliwiając synchroniczną i asynchroniczną komunikację w czasie i asynchroniczną w przestrzeni. Jest darmowy, nie wymaga zakupu licencji, jest więc łatwo dostępną i bezkosztową pozycją z perspektywy organizacji badań. Co ważne dla rozmówców troszczących się o swoją anonimowość, konto użytkownika można założyć bez podawania prawdziwych danych ${ }^{3}$, a od niedawna rozmowy przez Skype'a można prowadzić bez zalogowania się i zainstalowania programu (usługa Meet Now, https:// www.skype.com/en/free-conference-call/). Połączenia prywatne audio i wideo, a także transfer plików są szyfrowane. Z perspektywy organizacji badań ważne jest też to, że jest to program uniwersalny. Działa on na komputerach stacjonarnych/laptopach i urządzeniach mobilnych w systemach Windows, Linux, Apple i Android, a także na wszystkich przeglądarkach. Skype umożliwia także połączenia (rozmowy telefoniczne, SMS) z telefonami stacjonarnymi i komórkowymi, co zwiększa szanse, że potencjalny uczestnik badania dysponuje sprzętem i systemem umożliwiającym wzięcie udziału w badaniu (Weller 2015; Peach 2021). Dodatkową zaletą jest czat, który można wykorzystać podczas wywiadu, gdy pojawiają się problemy z połączeniem lub też (w trakcie lub po wywiadzie) wymienić się za

\footnotetext{
${ }^{2}$ Do końca 2012 r. 25\% wszystkich rozmów międzynarodowych było wykonywanych przez Skype (Miller, Sinanan 2014 za Adams-Hutcheson, Longhurst 2017). W marcu 2020 r. firma Microsoft ogłosiła, że dziennie ze Skype korzysta 40 mln osób (https://antyweb.pl/skype-2021-liczba-uzytkownikow-nowe-funkcje [dostęp 3.11.2021]).

${ }^{3}$ Cecha ta może być przez niektórych badaczy postrzegana jako wada. Do tego wątku powrócę w dalszej części tekstu.
} 
jego pośrednictwem dodatkowymi informacjami, na przykład linkiem do przydatnej strony internetowej, numerem telefonu do instytucji lub większą liczbą materiałów i informacji (jak np. grafiki, zdjęcia, pliki audio lub wideo ${ }^{4}$ ) (Batorski, Olcoń-Kubica 2006; Deakin, Wakefield 2014; Given, Saumure 2015; Lo Iacono i in. 2016; Adams-Hutcheson, Longhurst 2017; Sipes, Roberts, Mullan 2019). Oczywiście tego typu materiały można udostępnić także podczas wywiadów twarzą w twarz, ale często wymaga to dodatkowego sprzętu i rekwizytów.

Badacze doceniają także to, że Skype oferuje możliwość nagrywania rozmów audio/wideo. Rejestrowanie wywiadu można rozpocząć jednym kliknięciem i jest ono sygnalizowane czerwoną lampką, widoczną dla wszystkich uczestników, którzy mają przez 30 dni dostęp do nagrania (jest ono przechowywane w chmurze, można je pobrać na swoje urządzenie). Cały proces jest więc transparentny, zarówno w momencie rozpoczynania, wstrzymania czy zakończenia nagrywania, jak i dysponowania plikiem. To, że badany na równi z badaczem ma dostęp do nagrania (co zwykle nie jest praktykowane w wywiadach twarzą $w$ twarz rejestrowanych za pomocą dyktafonu), jest ważne z punktu widzenia etyki badań i jest narzędziem wyrównywania asymetrii władzy w wywiadzie.

Wskazane cechy skłoniły wielu badaczy do tego, by w swoich projektach wykorzystać program Skype. Niektórzy z nich od razu zakładali, że przeprowadzą wywiady online za jego pośrednictwem (np. Brown 2018); inni pozostawiali badanym decyzję, czy chcieliby rozmawiać twarzą w twarz, czy też przez komunikator (Hanna 2012; Deakin, Wakefield

\footnotetext{
${ }^{4}$ Istotnym czynnikiem ograniczającym skorzystanie z tych możliwości jest przepustowość łączy internetowych badacza i badanych (Batorski, Olcoń-Kubicka 2006).
}

2014; Adams-Hutcheson, Longhurst 2017; Whale 2017); niektórzy badacze zostali „zmuszeni” do wyboru tej techniki (np. ze względu na pandemię; Krauz 2020); zdarzało się także, że to uczestnik badania proponował taką formę wywiadu jako dogodniejszą (np. Jakubowska 2016). Poniżej przedstawię korzyści, jakie wiążą się w tym wyborem, oraz ryzyka, jakie trzeba wziąć pod uwagę, aby dobrze zaplanować badania z wykorzystaniem wywiadów przez Skype'a.

\section{Zalety wywiadów zapośredniczonych przez Skype'a}

Jedną z głównych zalet wywiadów realizowanych przez Skype'a, co można docenić, porównując je z wywiadami telefonicznymi (będącymi prekursorami i alternatywą dla wywiadów online), jest możliwość zobaczenia się badacza i badanego. Wideokonferencja umożliwia uczestnikom wywiadu wzajemną obserwację mimiki, mowy ciała, otoczenia i wszelkich artefaktów, które mają znaczenie dla poruszanego tematu (np. w badaniu Whale [2017] dzięki kamerze internetowej rozmówcy pokazywali badaczce przygotowane przez siebie rysunki i notatki). Co ważne, połączenie wideo jest opcjonalne. Jeśli rozmówca woli nie włączać kamery, ma taką możliwość.

Badacze wykorzystujący ten rodzaj wywiadu zwracają uwagę na jego niższe koszty (w wymiarze finansowym i temporalnym) w porównaniu do wywiadów bezpośrednich, dzięki rezygnacji z podróży oraz wynajmowania przestrzeni do prowadzenia wywiadów (Glassmeyer, Dibbs 2012; Deakin, Wakefield 2014; Given, Saumure 2015; Lo Iacono i in. 2016; Whale 2017; Brown 2018; Archibald i in. 2019; Jenner, Myers 2019; Krouwel i in. 2019). Jak zauważają Sipes, Roberts i Mullan (2019), dotyczy to również 
badanych, którzy także nie muszą ponosić kosztów związanych z logistyką uczestnictwa w projekcie.

Dla wielu badaczy i badanych dodatkowym argumentem za realizowaniem wywiadów online jest ekologia. Wyrazistym tego przykładem może być projekt Hanna (2012), dotyczący turystyki zrównoważonej, w którym wszyscy uczestnicy, do których badacz musiałby dojechać lub dolecieć, zdecydowali się na rozmowy telefoniczne lub przez Skype'a.

Oszczędność czasu i pieniędzy związana z nieodbytymi podróżami otwiera nowe możliwości poszukiwania rozmówców - już bez ograniczeń geograficznych (Lo Iacono i in. 2016; Seitz 2016). Dzięki temu Lo Iacono, Symonds i Brown (2016) byli w stanie przeprowadzić wywiady z osobami praktykującymi taniec raqs sharqi zrekrutowanymi w czterech krajach, a także z podróżnikami, którzy w czasie wywiadu przebywali w pięciu krajach świata. Badacze mogą więc łatwiej niż w wywiadach bezpośrednich poszerzyć zakres swojej próby, umiędzynarodawiając ją ${ }^{5}$ (Deakin, Wakefield 2014; Cin i in. 2016; Lo Iacono i in. 2016). Wydaje się to być szczególnie obiecujące przy poszukiwaniu przypadków do porównań w teoretycznym doborze próbek (Glaser, Strauss 2009). Wywiady online pozwalają także włączyć do próby osoby, które ze względu na ich miejsce zamieszkania mogły być dotychczas wykluczone z badań bezpośrednich (Given, Saumure 2015). Miner i współpracownicy (2011) w swoich badaniach dotyczących osób transpłciowych osiągnęli nadreprezentację (w porównaniu do innych badań) osób zamieszkałych poza miastami. Dzięki wywiadom online dotarli więc do osób, które nie miały wcze-

${ }^{5} \mathrm{~W}$ artykule pomijam kwestię sposobów rekrutacji uczestników badań, jako odrębne zagadnienie, niedeterminujące wyboru techniki prowadzenia wywiadu online lub bezpośredniego. śniej możliwości opowiedzieć badaczom o swoich doświadczeniach.

W czasie pandemii COVID-19 (szczególnie w czasie lockdownów) dodatkową zaletą wywiadów przez Skype'a było to, że mogły się one odbyć bez konieczności fizycznego spotkania się. Jednak należy pamiętać, że właśnie ta cecha była kluczowa dla wielu badaczy realizujących swoje projekty przed pandemią z osobami mającymi trudności z przemieszczaniem się (np. z powodu niepełnosprawności, choroby), przebywającymi w izolacji/ukrywającymi się, mającymi niewiele wolnego czasu i napięte terminarze (np. specjaliści, menedżerowie) oraz szczególnie mocno chroniącymi swoją prywatność (np. mniejszości seksualne, populacje ukryte) (Batorski, Olcoń-Kubicka 2006; Miner i in. 2011; Deakin, Wakefield 2014; Weller 2015; Jemielniak 2019; Jenner, Myers 2019). W badaniu Stojkow i Żuchowskiej (2014) znaczna część wywiadów została przeprowadzona za pośrednictwem Skype'a, ponieważ był on dostępny dla wszystkich rozmówców, niezależnie od stopnia i rodzaju doświadczanej niepełnosprawności (np. w przypadku osób niesłyszących wykorzystano czat, co pozwoliło na komunikację bez pośrednictwa osób trzecich).

Zwolennicy wywiadów poprzez Skype’a zwracają także uwagę na to, że zapewniają one badaczowi i badanym poczucie bezpieczeństwa fizycznego i emocjonalnego. Jak zauważają Krouwel, Jolly i Greenfield (2019), badacz ani badani nie muszą udawać się $\mathrm{W}$ nieznane przestrzenie, postrzegane przez nich jako niebezpieczne, wywołujące niepewność czy skrępowanie ${ }^{6}$. Było to ważne na przykład w ba-

\footnotetext{
${ }^{6} \mathrm{Na}$ interesujący wątek emocjonalnego bezpieczeństwa badacza zwraca uwagę Whale (2017), pisząc o tym, że po wyczerpujących emocjonalnie wywiadach z nastolatkami doświadczającymi problemów z nietrzymaniem moczu było jej trudno pozostawać $\mathrm{w}$ domu badanego, a następnie samotnie wracać
} 
daniach Peach (2021), która jest przekonana, że dla niektórych jej rozmówców, studentów doświadczających zaburzeń psychicznych, konieczność wyjścia z domu i dojechania na wywiad mogłaby stanowić barierę uczestnictwa w projekcie. Fizyczne oddalenie w wywiadach online może być przez wielu rozmówców postrzegane jako mniej inwazyjne (Weller 2017). Sprzyja też większemu poczuciu anonimowości. Rozmówcy nie muszą podawać badaczowi swojego numeru telefonu, adresu zamieszkania ani żadnych innych danych wrażliwych, jedynie nazwę użytkownika Skype (która nie musi być ich prawdziwym imieniem czy nazwiskiem) (Hanna 2012; Deakin, Wakefield 2014; Jenner, Myers 2019). Rozmówca może użyć swojego prywatnego konta Skype, założyć nowe wyłącznie na potrzeby wywiadu lub też skorzystać z opcji rozmowy bez logowania. Jest to szczególne ważne $\mathrm{w}$ badaniach dotyczących tematów drażliwych, gdzie to, że badani mogą sami zdecydować, jak wiele informacji o sobie ujawnią, może przesądzić o ich zgodzie na udział w badaniu (por. Peach 2021).

Na interesującą kwestię zwracają uwagę Sipes, Roberts i Mullan (2019), zauważając, że Skype pozwala na zablokowanie niechcianych kontaktów, co daje uczestnikowi badań możliwość zablokowania badacza. Rozmówca może to wykorzystać na przykład jeśli przerwie wywiad lub ukończy go, ale nie chce, aby badacz zadawał mu dodatkowe pytania. Może on wtedy usunąć kontakt lub zablokować badacza, aby mieć pewność, że ten nie skontaktuje się z nim ponownie (Deakin, Wakefield 2014). Funkcja ta może być postrzegana jako zaleta lub wada, w zależności od tego, jak badacz definiuje rolę swoją i badanego.

do siebie. Preferowała ona wywiady zdalne, podczas których dzielił ją dystans od badanych, zaś trudne emocje, które pojawiły się podczas rozmowy, mogła omówić ze współpracownikami pracującymi w sąsiednich gabinetach.
Z perspektywy rozmówcy może to zwiększać jego poczucie kontroli nad sytuacją wywiadu (Sipes i in. 2019). Jak zauważają Sipes, Roberts i Mullan (2019), także badacz może po wywiadzie zablokować swojego rozmówcę, co może być pomocne, jeśli relacja z badanym znacznie wykroczyła poza ramy badawcze i staje się dla badacza trudna (por. Palęcka 2021).

Kolejną zaletą wywiadu poprzez Skype'a jest to, że pozwala on na elastyczne dopasowanie terminu wywiadu do sytuacji życiowej rozmówcy, a nagłe zmiany planów (badacza lub badanych) nie powodują dodatkowych kosztów. Podkreśla to Weller (2015), której rozmówcami byli młodzi ludzie żyjący $\mathrm{w}$ rozjazdach między domem rodzinnym a miejscem studiowania, dzielący swój czas między studia i pracę i nierzadko mieszkający $\mathrm{w}$ prekarnych warunkach. Z tych powodów badaczce byłoby trudno umówić się z nimi na wywiad bezpośredni. Elastyczność wywiadów przez Skype’a była bardzo ważna także dla Brown (2018), która realizowała wywiady $\mathrm{z}$ osobami chorującymi na fibromialgię. Ze względu na to, że choroba ta ma nieprzewidywalny przebieg, a stan chorego dynamicznie się zmienia, kluczowe dla badaczki było to, aby zapewnić rozmówcom komfort elastycznego wyboru miejsca wywiadu (bez konieczności dojazdu) oraz jego terminu (z możliwością odwołania spotkania w zależności od ich samopoczucia) i długości trwania. Było to ważne ze względów praktycznych, ale i etycznych. Jak zauważa Brown, choć odwołanie wywiadu przez rozmówcę w ostatniej chwili było dla niej kłopotem, to jednak $\mathrm{w}$ przypadku wywiadów online znacznie mniejszym, niż gdyby była już w drodze na spotkanie twarzą w twarz. Brown zauważa także, że uczestnicy otwarcie relacjonowali swój stan zdrowia i korzystali z możliwości przełożenia spotkania, co byłoby dla nich trudniejsze, gdyby swoje decyzje podejmowali ze świadomością tego, że przy- 
czyniają się do zwiększania kosztów (np. podróży) ponoszonych przez badaczkę. Rozmówcy korzystali także często z możliwości podzielenia wywiadu na kilka mniej obciążających spotkań w ciągu kilku dni, co zdaniem Brown sprawiało, że zgromadzone dane były lepszej jakości, ponieważ rozmówcy nie byli zmęczeni długą rozmową.

Na koniec warto także wspomnieć o tym, że choć w (szczególnie rodzimej) literaturze niekoniecznie uważa się, że wywiad online jest przyjazny badaczowi, to dla niektórych badaczy może być on bardziej komfortowy niż wywiad bezpośredni. Jak przyznaje Weller (2015), często czuła się ona swobodniej podczas zdalnych wywiadów, szczególnie tych jedynie audio. Mogła wtedy koncentrować się na przebiegu wywiadu, nie zaś na tym, jakie wrażenie wywiera na rozmówcach. Wspomina ona o tym w kontekście korzystania z przygotowanej wcześniej listy pytań (która była rozbudowana i opatrzona fragmentami wywiadów zrealizowanych podczas trzech wcześniejszych fal jej badań podłużnych dotyczących różnych aspektów życia młodych Brytyjczyków), co przy wywiadach online robiła bez poczucia, że może zostać uznana za niekompetentną (Weller 2015). Uwaga ta jest dla mnie cenna nie tylko dlatego, że autorka ujawnia trudności związane $\mathrm{z}$ realizacją swojej roli, ale także dlatego, że zwraca uwagę na komfort badaczki/badacza, który także jest istotny dla przebiegu i uzyskanych efektów procesu gromadzenia danych.

Podsumowując zalety wywiadów online, warto zauważyć, że w literaturze nie poświęca się wiele miejsca różnego rodzaju kosztom prowadzonych badań, a badacze raczej nie pokazują kuchni organizacyjnej swoich projektów. Odwołując się do własnych doświadczeń, wydaje mi się jednak, że prozaiczne kwestie takie jak: szukanie możliwie najlepszych połączeń do miejsca zamieszkania rozmówcy, godziny spędzone w podróży oraz na czekaniu na wywiad, stres związany $z$ reorganizacją życia rodzinnego i zawodowego, wywołaną przez częste wyjazdy, zaskoczenia i niedogodności w miejscu wywiadu czy (nie)rozliczanie delegacji to koszty przemilczane, a jednak wpływające na jakość pracy badacza. Wa to także wspomnieć, że zastosowanie wywiadów online jest czynnikiem demokratyzującym badania społeczne, zarówno w wymiarze badacz-badany, jak i w ramach akademii, ponieważ dzięki ich zastosowaniu można choć częściowo zneutralizować nierówności na przykład w dostępie do środków finansowych czy ilości czasu, jakimi dysponują badacze (Lo Iacono i in. 2016). Wykorzystanie wideokonferencji otwiera także wiele możliwości wspólnych działań badawczych i zaproszenia do zespołu osób nawet znacznie od siebie oddalonych przestrzennie (Braun i in. 2020). Może być też sposobem na realizowanie projektów partycypacyjnych $\mathrm{w}$ niehierarchicznej przestrzeni online.

\section{Trudności w realizacji wywiadów zapośredniczonych przez Skype’a}

Wywiady online, choć dają możliwość pokonania niektórych trudności organizacyjnych, przed jakimi stoją badacze, nie są jednak wolne od ograniczeń. Wiele $\mathrm{z}$ nich jest ściśle związanych ze stosowaną technologią, a więc z jakością posiadanego sprzętu i połączenia internetowego. Do najpoważniejszych należą: ryzyko przerwania połączenia (Bielska i in. 2021) oraz kłopoty z jego jakościa, przede wszystkim zawieszenie się, „zamrożenie” obrazu lub/i dźwięku (Given, Saumure 2015; Weller 2017; Whale 2017). Oczywiście w takich sytuacjach można ponownie nawiązać połączenie lub poczekać chwilę na poprawę jego jakości, jednak takie nagłe prze- 
rwanie rozmowy zaburza jej płynność i zagraża budowanej atmosferze wywiadu, co może być szczególnie kłopotliwe, jeśli jego temat jest drażliwy lub intymny (Seitz 2016; Whale 2017). Niektórzy badacze stosujący wywiady poprzez Skype'a opisywali także problemy z dźwiękiem (jego jakością i poziomem głośności) (Winzenburg 2012; Seitz 2016; Whale 2017). Wynikały one ze słabej jakości połączenia internetowego i/lub używanego mikrofonu, działań rozmówcy (np. zbytnie oddalenie się od mikrofonu), ale i zakłóceń (np. ze strony osób trzecich: współlokatorów, członków rodziny, zwierząt domowych) w pomieszczeniu, w którym przebywał rozmówca (Krouwel i in. 2019). W tym kontekście ważny jest wybór optymalnego miejsca wywiadu: cichego pomieszczenia ze stabilnym Internetem (Winzenburg 2012; Seitz 2016; Whale 2017). Jednakże nie zawsze rozmówcy (ale i badacze) mają dostęp do takiej przestrzeni, co było szczególnie widoczne w czasie pandemii, kiedy praca i edukacja przebiegały online. Zarówno obciążenie łączy, jak i liczba osób, które przebywały razem w mieszkaniu, a także związane $z$ tą sytuacją napięcie emocjonalne utrudniały realizację wywiadów przez Skype'a.

Trzeba jednak pamiętać, że w wywiadach twarzą $\mathrm{w}$ twarz także zdarzają się problemy ze sprzętem (dyktafonem, kamerą): baterie mogą się wyczerpać, mikrofon zepsuć, nagranie z dyktafonu może okazać się na etapie transkrypcji mało słyszalne, silnie zakłócone szumami z tła i tak dalej (Hanna 2012). W każdym przypadku, nie tylko podczas wywiadów online, warto więc być świadomym potencjalnych komplikacji związanych z technologia, zapobiegać im, a jeśli jest to możliwe, mieć przygotowany plan B (por. Sullivan 2012; Jenner, Myers 2019). Przykładem mogą być działania podejmowane przez Deakin i Wakefield (2014), które w momentach silnego zakłócenia dźwięku podczas wywia- dów przez Skype’a zapisywały poszczególne słowa czy całe pytania/odpowiedzi na czacie, a następnie włączały je do transkrypcji wywiadu. W niektórych przypadkach konieczne było także dopytywanie i prośby o powtórzenie. Tego typu zakłócenia niekoniecznie muszą jednak oznaczać, że relacja badaczbadany ucierpi. Jak zauważają Weller (2015) oraz Krouwel, Jolly i Greenfield (2019), różnego rodzaju kłopoty w zakresie technologii, które pojawiały się podczas realizowanych przez nich wywiadów online, były doświadczeniem, które zbliżało do siebie badacza i badanego. Podczas wspólnego poszukiwania rozwiązań łatwiej było bowiem redefiniować relacje władzy, co sprzyjało otwartości rozmówców. W wywiadach zapośredniczonych przez Skype'a wyraźnie (być może wyraźniej niż w spotkaniach twarzą w twarz) widać więc, że nie tyle badacz jest ekspertem, który zabezpieczy wszystkie aspekty wywiadu, co obie strony są (powinny być) aktywnie zaangażowane $\mathrm{w}$ pracę nad jego przebiegiem.

Nieco inną kwestią jest ryzyko, że badanym trudno będzie utrzymać skupienie $\mathrm{w}$ trakcie rozmowy online i będą angażować się równocześnie $\mathrm{w}$ wiele dodatkowych czynności (np. pisać wiadomości tekstowe $\mathrm{w}$ telefonie, korzystać $\mathrm{z}$ innych stron internetowych, mediów społecznościowych) (Jemielniak 2019; Lobe i in. 2020; Bielska i in. 2021). Ryzyko to uaktywnia się szczególnie $\mathrm{w}$ przypadku wywiadów jedynie audio, bez użycia kamery internetowej. W tym kontekście ważne jest wcześniejsze uzgodnienie z rozmówcami tego, by zamknęli wszystkie strony i aplikacje oraz wyciszyli powiadomienia, które mogłyby ich rozpraszać (Lobe i in. 2020).

Kolejną potencjalną trudnością jest ryzyko związane z nadużywaniem przez rozmówców elastyczności, jaka cechuje wywiady online. Niektórzy badacze obawiali się, że może się to przełożyć na wyższy poziom 
absencji uczestników, czyli sytuacje, gdy rozmówcy, mimo umówienia się na wywiad, nie pojawią się na nim, co jest łatwiejsze online niż w przypadku, gdyby spotkanie odbywało się $\mathrm{w}$ miejscu zamieszkania czy pracy badanego (Deakin, Wakefield 2014). Inną obawą opisywaną w literaturze przedmiotu jest możliwość łatwiejszego niż przy wywiadach twarzą w twarz przerwania wywiadu przez badanego (Adams-Hutcheson, Longhurst 2017). I choć w każdym wywiadzie rozmówca ma prawo wycofać się $\mathrm{w}$ dowolnym momencie, to jednak interakcyjnie znacznie trudniej jest wyjść z wywiadu bezpośredniego, niż rozłączyć się online. Niektórzy badacze spodziewali się więc, że części wywiadów nie uda się dokończyć lub będą one wielokrotnie przekładane przez rozmówców. W tym kontekście interesujące są obserwacje Brown (2018), której rozmówcy, ze względu na stan zdrowia, wielokrotnie korzystali z możliwości przerwania wywiadu i kontynuowania go w innym terminie. Mimo związanych z tym niedogodności, dostrzegała ona jednak pozytywne konsekwencje tej sytuacji, w postaci zbudowania z badanymi głębszej relacji, opartej na wielokrotnych rozmowach. Także inni autorzy podkreślali, że łatwo dostępna możliwość, by w każdej chwili przerwać wywiad, dawała rozmówcom poczucie większej kontroli nad jego przebiegiem, co zmniejszało asymetrię władzy w wywiadzie (Janghorban, Roudsari Latifnejad, Taghipour 2014; Cin i in. 2016; Whale 2017; Sipes i in. 2019) i przyczyniało się do większego zaangażowania w rozmowę osób, które mimo dostępności nie skorzystały z tej opcji (Bertrand, Bourdeau 2010).

Innym ograniczeniem stosowania wywiadów online są utrudnienia przy doborze próby. Jak wspominałam, wywiady zapośredniczone są doceniane przez badaczy za to, że pozwalają prowadzić badania rozproszonych geograficznie i trudno dostęp- nych populacji (Miner i in. 2011). Jednak pojawiają się wątpliwości, czy możliwe jest skuteczne zrekrutowanie uczestników wyłącznie poprzez kontakt online. Weller (2015), opisując swoje pozytywne doświadczenia związane z realizacją wywiadów przez Skype'a, zauważa, że źródłem sukcesu mogła być wcześniejsza znajomość z rozmówcami, zapoczątkowana podczas realizacji wywiadów bezpośrednich $\mathrm{w}$ poprzednich falach jej projektu. Tylko $42 \%$ uczestników jej badań zadeklarowało, że zgodziliby się na udział w badaniu online nawet, jeśli nie znaliby wcześniej badaczki. Wskazuje to na pewien stopień niechęci lub wahania wśród uczestników do angażowania się w projekt badawczy z wykorzystaniem zapośredniczonych form komunikowania się. Z kolei Deakin i Wakefield (2014) wskazują, że jedyne przypadki niestawienia się na wywiad mimo wcześniejszego umówienia się miały miejsce wśród uczestników, których badaczki nie znały przed wywiadem. W tej grupie nie udało się zrealizować $15 \%$ wywiadów, podczas gdy wszyscy rozmówcy, których badaczki znały wcześniej, stawili się na wywiad. Dla powodzenia wywiadów online ważne może być więc nawiązanie relacji z rozmówcą (choćby przez wymianę maili) jeszcze przed wywiadem.

Innym utrudnieniem przy doborze rozmówców jest istnienie cyfrowych nierówności, związanych z dostępem do Internetu (i jego jakością), posiadanymi umiejętnościami korzystania z sieci, docierania do informacji i komunikowania się z innymi (Batorski 2005; 2009). Badacze zwracają uwage na to, że przedstawiciele starszych generacji ${ }^{7}$ oraz grup

\footnotetext{
7 Warto także przywołać obserwację Lo Iacono, Symondsa i Browna (2016), którzy zauważyli, że w przypadku ich badań rozmówcy w wieku powyżej 70. roku życia swobodnie korzystali z technologii VoIP (Voice over Internet Protocol), podczas gdy niektórzy znacznie młodsi uczestnicy przyznali, że mieli problemy z nawiązaniem połączenia. Ich zdaniem osoby starsze są skłonne stosować nowe technologie w celach praktycznych. „Onlinizacja” komunikacji, jaka ma miejsce w czasie
} 
posiadających ograniczone zasoby (także w postaci dostępu do komputera, smartfonu z Internetem, stabilnego połączenia z siecią), niskie kompetencje technologiczne oraz niski poziom kapitału społecznego i kulturowego mogą niechętnie brać udział, odmawiać czy wręcz być wykluczeni z badań online (Sullivan 2012; Deakin, Wakefield 2014; Nehls, Smith, Schneider 2015; Cin i in. 2016; Seitz 2016; Stachura 2016; Foley 2021). Warto także pamiętać, że większość badań z wykorzystaniem Skype’a zrealizowano z udziałem badaczy i rozmówców z globalnej Północy. Zastosowanie Skype’a nie jest więc gwarantem unieważnienia dysproporcji w dostępie do infrastruktury technicznej i różnic społecznych, wpływających na przebieg procesu badawczego (Cin i in. 2016). Nadal aktualne pozostaje wyzwanie, aby szukać sposobów na umożliwienie osobom zajmującym nieuprzywilejowane pozycje społeczne udziału w badaniach i wyrażenia swojej perspektywy (Nind i in. 2021).

\section{Czy podczas wywiadu poprzez Skype'a można nawiązać relację?}

Jedną z podstawowych obaw badaczy sceptycznie nastawionych do wywiadów przeprowadzanych za pośrednictwem Skype'a (i innych komunikatorów) jest to, czy możliwe jest, aby w ten sposób nawiązać głębszą, a nie jedynie powierzchowną relację z badanym. Czy będzie ona równie dobra, jak w wywiadach twarza $w$ twarz? Czy pewne wymiary tej relacji nie zostaną bezpowrotnie utracone? Poniżej, opierając się na literaturze przedmiotu, omówię refleksje badaczy na temat tego, jak wspomóc proces budowania relacji z uczestnikami badań online.

pandemii, prawdopodobnie jeszcze przyspieszyła proces akulturacji tych aplikacji, co warto wziąc pod uwagę w procesie planowania badań.

\section{Co sprzyja budowaniu relacji badacz-badany poprzez Skype'a}

Podstawą niezbędną do nawiązania relacji z badanym jest zaufanie, które pozwala rozmówcy poczuć się komfortowo i otworzyć się przed badaczem (Lo Iacono i in. 2016; Ślęzak 2018). Aby mogło się ono rozwinać podczas interakcji zapośredniczonej przez technologię, bardzo ważne jest zaznajomienie się obu stron $\mathrm{z}$ oprogramowaniem, tak aby nie było ono źródłem niepewności. Badacze stosujący wywiady poprzez Skype'a zwracali uwagę na to, że był on oswojony przez rozmówców, ponieważ większość z nich już wcześniej korzystała z tego programu do prywatnych rozmów z rodziną czy przyjaciółmi. Dlatego też nie czuli się oni skrępowani ani technologią, ani faktem włączonej kamery (Seitz 2016; Brown 2018). Można w tym miejscu przywołać słowa uczestników badań Weller (2015), dla których wywiad badawczy przez Skype'a był przyjemnym doświadczeniem, podobnym do rozmów, jakie regularnie odbywają online z przyjaciółmi, w których, dzięki użyciu kamery, ma się wrażenie przebywania obok siebie. W tym kontekście na interesującą kwestię zwraca uwagę Whale (2017), zauważając, że dla większości młodych ludzi i dzieci formalny wywiad badawczy twarzą w twarz jest typem interakcji, jakiego nie znają. Ponieważ jednak są oswojeni $z$ różnego rodzaju aplikacjami, za pomocą których regularnie rozmawiają z rodziną i przyjaciółmi, mogą więc czuć się bardziej swobodnie w tego rodzaju wywiadzie. Może być on dla nich także bardziej interesujący, co zwiększa szanse na ich uczestnictwo w projekcie (de Rosnay 2006 za Bertrand, Bourdeau 2010). Badacze, którzy koncentrują się na danych wizualnych, zwracają z kolei uwagę na to, że nagrywanie podczas wywiadów online może być postrzegane przez badanych jako mniej pro- 
blematyczne i bardziej naturalne niż w sytuacji, gdy podczas wywiadu twarzą w twarz w pokoju stoi kamera (Brown 2018).

Bardzo ważną kwestią ułatwiającą budowanie relacji badacza i badanego jest zmiana relacji władzy i większy niż w wywiadach twarzą w twarz w pływ rozmówców na wiele wymiarów spotkania. Jakjuż wspominałam, mogą oni w większym stopniu decydować o terminie i czasie trwania wywiadu, zakresie osobistych danych, jakie przekażą badaczowi, a także miejscu przeprowadzania wywiadu. Wybór przez rozmówców przestrzeni, która jest dla nich dogodna i bezpieczna, ma duży wpływ na to, jak się czują i na ile są w stanie otworzyć się podczas wywiadu. Wywiad poprzez Skype'a może być przeprowadzony $\mathrm{w}$ zasadzie $\mathrm{w}$ dowolnej lokalizacji, w której obie strony będą miały dostęp do Internetu oraz komputera, laptopa czy telefo$\mathrm{nu}^{8}$. Mogą więc wybrać miejsce, w którym czują się komfortowo (Hanna 2012; Deakin, Wakefield, 2014; Jenner, Myers 2019), co dla każdego z rozmówców i dla badacza może oznaczać inną lokalizację (Sipes $i$ in. 2019). W badaniach Peach (2021) niektórzy uczestnicy wybrali bardzo prywatne, intymne przestrzenie (np. własne łóżko) jako miejsce udzielenia wywiadu. W tym samym czasie badaczka przebywała w swoim gabinecie (w miejscu pracy lub w domu). Wybór przestrzeni, w której każda ze stron przebywa podczas wywiadu, jest więc także sam w sobie interesującą informacją na temat tego, jak definiują one sytuację badawczą.

\footnotetext{
${ }^{8}$ Uczestnicy badań online preferują jednak zwykle przestrzenie prywatne. W badaniach Jenner i Myersa (2019) rozmówcy mogli wybrać zarówno to, czy chcą udzielić wywiadu twarzą w twarz, czy poprzez Skype'a, jak i miejsce, $\mathrm{w}$ którym odbędzie się rozmowa. W rezultacie wywiady bezpośrednie odbyły się w zróżnicowanych przestrzeniach publicznych i prywatnych, zaś te przez Skype'a wyłącznie w prywatnych.
}

Warto także pamiętać, że przestrzeń uosabia pewne hierarchie władzy, a to na czyim terenie odbywa się wywiad (np. w instytucji badacza, mieszkaniu badanego) może zmniejszać lub zwiększać asymetrię władzy (por. Cin i in. 2016). Jeśli podczas wywiadu poprzez Skype'a badani przebywają w swoim domu, to dzięki włączeniu, wyłączeniu czy odpowiedniemu skierowaniu kamery mogą decydować, na ile zaprosić do niego badacza: mogą oprowadzić go po całym mieszkaniu, pokazując te miejsca, przedmioty, osoby, zwierzęta, które są dla nich ważne, ale równie dobrze mogą pozostawić kamerę wyłączoną (Lo Iacono i in. 2016; Brown 2018). Rozmówca ma więc większą kontrolę nad tym, czy i jakie elementy sceny i kulis (Goffman 2000) pokaże, co dostarcza też dodatkowych danych na temat jego sposobu prezentacji siebie (Lo Iacono i in. 2016). Badacz natomiast unika poczucia fizycznego narzucania się w prywatnej przestrzeni rozmówców (Hanna 2012). Jest to ważne także z perspektywy etyki badań, ponieważ ustalone przez rozmówcę granice między tym, co prywatne i publiczne w kontekście wywiadu przez Skype'a trudniej jest badaczowi przypadkiem lub intencjonalnie naruszyć niż w przypadku, gdy jest gościem w domu badanego (Sipes i in. 2019; Peach 2021). Zmniejsza się także ryzyko zamazania granic i pojawienia się wyzwań związanych na przykład z reagowaniem na rozbudowane przejawy gościnności badanych (np. Chiswell, Wheeler 2016 za Peach 2021; por. Rostocki 1999; Horolets 2016).

W wielu publikacjach opisujących zastosowanie wywiadu poprzez Skype'a zwraca się uwagę na to, że większa kontrola nad miejscem przeprowadzenia wywiadu jest szczególnie ważna dla niektórych kategorii rozmówców, na przykład osób doświadczających choroby czy niepełnosprawności. W przypadku uczestników badań Brown (2018), osób chorujących na fibromialgię, ważne było nie tylko 
to, że mogli oni pozostać w domu w czasie trwania wywiadu, co oszczędzało im trudności związanych z przemieszczaniem się, ale także to, że jeśli podczas rozmowy poczuli się gorzej, bez żadnych problemów czy zakłopotania mogli położyć się, przyjąć inną pozycję czy pospacerować po pokoju. Jak zauważa Brown, dzięki temu było bardziej prawdopodobne, że wywiady w ogóle się odbędą, szczególnie w okresach gorszego samopoczucia uczestników. Z kolei Peach (2021), prowadząc wywiady z osobami doświadczającymi niepełnosprawności fizycznej oraz zaburzeń w obszarze zdrowia psychicznego, zauważa, że wywiad twarzą w twarz w miejscu publicznym lub jej gabinecie wiązałby się $\mathrm{z}$ barierami uczestnictwa, ponieważ mógłby być postrzegany przez jej rozmówców jako zbyt formalny, onieśmielający i ryzykowny z perspektywy poczucia anonimowości.

Można więc zauważyć, że dystans fizyczny, jaki oferują wywiady zapośredniczone, nie przeszkadza w budowaniu relacji z uczestnikami badania. Jak wyjaśnia Weller (2017), choć współobecność, poczucie bycia razem są bardzo ważne, to realizując wywiady biograficzne online w czwartej fali badania longitudalnego, przekonała się, że nie musi być to współobecność fizyczna. Obraz z kamery internetowej lub nawet jedynie dobrej jakości dźwięk wystarczały, by nawiązać dobry kontakt z rozmówcami i to nierzadko w łatwiejszy sposób niż miało to miejsce podczas rozmów twarzą $w$ twarz we wcześniejszych falach badania. Uczestnicy wywiadów przez Skype'a doświadczali mniejszej presji i niepokoju, czuli się bardziej zrelaksowani i w rezultacie udzielali bardziej przemyślanych i pogłębionych odpowiedzi (Weller 2017; zob. także Deakin, Wakefield 2014). Współobecność $\mathrm{w}$ wywiadach online miała więc raczej charakter emocjonalny i przekraczała ograniczenia związane z zapośredniczoną interak- cją. Jednocześnie fizyczna nieobecność badaczki pozwalała ograniczyć jej ingerencję $\mathrm{w}$ „terytoria Ja" (Goffman 2011) uczestników, co zmniejszało ryzyko odczuwania przez nich zakłopotania (Weller 2017). Jest to szczególnie ważne przy budowaniu relacji $\mathrm{z}$ badanymi $\mathrm{w}$ przypadku trudnych tematów badawczych, na przykład dotyczących zaburzeń psychicznych (Peach 2021), tożsamości seksualnej (Sipes i in. 2019), przemocy rówieśniczej (Bouchard 2016), a także rozmów z osobami wykluczonymi, stygmatyzowanymi, podatnymi na zranienie, nieśmiałymi i introwertycznymi (Batorski, Olcoń-Kubicka 2006; Ślęzak 2013; Adams-Hutcheson, Longhurst 2017; Whale 2017). Efekt ten jest tym silniejszy, że rozmówca kontroluje przekaz wizualny. Miało to kluczowe znaczenie $\mathrm{w}$ wywiadach realizowanych przez Krauz z kobietami, które doświadczyły urazów twarzy w wyniku wypadku. Podczas niektórych wywiadów z użyciem kamery rozmówczynie i badaczka bardzo dokładnie pokazywały sobie swoje blizny, co miało moc tworzenia „niesamowitej płaszczyzny porozumienia" (Krauz 2020: 112). Jednocześnie niektóre kobiety decydowały się na rozmowę bez przekazu wideo, bez pokazywania twarzy, co byłoby niemożliwe w tradycyjnym wywiadzie i mogło być decydujące $\mathrm{w}$ podjęciu decyzji o udziale w projekcie.

Podsumowując, można zauważyć, że wielu badaczy opisujących swoje doświadczenia w obszarze budowania relacji z uczestnikami wywiadów przez Skype'a zwracało uwagę na bardzo dobry kontakt badacz-badany. To, co o nim decydowało, to nie fizyczna współobecność, ale znaczny zakres wpływu badanych na przebieg wywiadu, oddanie przez badacza części kontroli nad sytuacją badawczą (zob. Cin i in. 2016), a także wcześniejsze, pozytywne doświadczenia uczestnika w zakresie komunikacji online (Weller 2015; 2017). Część rozmówców inter- 
pretowała bowiem wywiad twarzą w twarz przez pryzmat formalnego, wywołującego niepokój spotkania, obciążonego dużą dysproporcją władzy, zaś rozmowę przez Skype'a postrzegała jako bardziej nieformalny i elastyczny wkład w projekt badawczy podobny do komunikowania się z bliskimi lub rówieśnikami (Weller 2015; 2017; Whale 2017).

\section{Co utrudnia budowanie relacji badacz-badany poprzez Skype'a}

Choć wielu autorów uważa, że zapośredniczony kontakt nie utrudnia budowania relacji z badanym, to w literaturze przedmiotu można jednak odnaleźć także bardziej ostrożne głosy. Adams-Hutcheson i Longhurst (2017) zauważają, że choć w niektórych kontekstach Skype pomaga budować więzi (np. między członkami rodziny, którzy nie mogą regularnie się spotykać), to w innych komunikacja zapośredniczona może być odbierana jako alienująca, zdominowana przez przedmioty (komputer, ekran, telefon). $\mathrm{W}$ ich badaniach dotyczaccych korzystania ze Skype'a i wpływu tego sposobu komunikowania się na codzienne życie większość uczestników deklarowała, że czuła się bardziej swobodnie, rozmawiając z osobą będącą fizycznie obok niż podczas wywiadów przez Skype'a. Planując wywiady online, trzeba więc wziąć po uwagę to, że choć część rozmówców będzie czuła się podczas nich komfortowo, to niektórzy nie odnajdą się $\mathrm{w}$ takim sposobie komunikowania się (Adams-Hutcheson, Longhurst 2017).

Zdaniem niektórych badaczy także temat wywiadu może wpływać na to, w jakim stopniu uda się nawiązać relację $\mathrm{z}$ badanym podczas rozmowy przez Skype'a. Jak uważa Seitz (2016), w tego typu wywiadzie bardziej osobiste pytania (w przypadku jej badań - dotyczące randek online) mogą być trud- ne dla rozmówców, ze względu na (jej zdaniem) mniejszą intymność $\mathrm{w}$ porównaniu $\mathrm{z}$ wywiadem tradycyjnym oraz włączoną kamerę, która mogła onieśmielać. Z kolei Foley (2021) zastanawia się, czy wywiady na temat śmierci i umierania z pacjentami, opiekunami i pracownikami służby zdrowia w opiece paliatywnej nie powinny być jednak przeprowadzane twarzą w twarz. Być może pozwoliłoby to łatwiej (dzięki fizycznej współobecności) udzielić rozmówcom wsparcia w sytuacjach, w których okaże się ono potrzebne. Wywiad bezpośredni dawałby także większe możliwości zaobserwowania i dekodowania niuansów $\mathrm{w}$ relacjach między pacjentami i opiekunami. Jednak, jak zauważa Foley, dla niektórych uczestników większe znaczenie może mieć możliwość zachowania prywatności we własnym otoczeniu, a także poczucie kontroli (którego w sytuacji ciężkiej choroby często są pozbawieni), jakie daje im wywiad online.

Jednym z największych ograniczeń zdalnych wywiadów jest to, że nie pozwalają one $\mathrm{w}$ taki sposób, jak jest to możliwe podczas interakcji twarzą w twarz, na obserwację sygnałów niewerbalnych. Warto jednak tę kwestię omówić oddzielnie dla wywiadów przez Skype'a z użyciem kamery oraz wykorzystujących jedynie przekaz dźwiękowy. Zubożenie komunikacji niewerbalnej jest bowiem bardziej dolegliwe w tym drugim przypadku (Deakin, Wakefield 2014: 605; Weller 2015; Sipes i in. 2019). Wyzwaniem dla badacza może być na przykład właściwa interpretacja momentów, w których rozmówca milczy. Bez obserwacji jego mowy ciała badacz może mieć wątpliwości, czy uczestnik potrzebuje dłuższej chwili zastanowienia nad odpowiedzia, jest skrępowany pytaniem czy też doszło do przerwania lub zakłóceń w połączeniu (Sipes i in. 2019). To, co może (i powinien) zrobić badacz w sytuacji niedostępności komunikatów niewer- 
balnych, to uważnie wsłuchiwać się i interpretować to, jak mówi badany, które słowa wypowiada ciszej, szybciej, które akcentuje, jaki jest ton jego głosu (Weller 2015). Powinien także podjać działania, aby zrekompensować rozmówcy brak komunikacji niewerbalnej ze swojej strony. Weller (2015) podczas wywiadów online, częściej niż w trakcie tradycyjnych, dokonywała werbalnych lub parawerbalnych wtrąceń, aby przekazać badanym swoje emocje, zaangażowanie, troskę, które w wywiadach bezpośrednich wyrażała przez mowę ciała. Nierzadko miała ona jednak obawy, że jej starania mogą być postrzegane przez rozmówców jako nieco sztuczne i powierzchowne.

W przypadku wywiadów, podczas których kamera nie jest włączona, dodatkową trudnością jest ograniczona wiedza badacza o interakcjach, które dzieją się „za kulisami”. Nie można mieć bowiem pewności, czy rozmówca jest w pomieszczeniu sam, czy też wraz z nim przebywają inne osoby, które są „ukrytą publicznością", wywierającą presję na to, jak się on prezentuje i co mówi (Rettie 2009). Z drugiej jednak strony podczas wywiadu online jest bardziej prawdopodobne, że rozmówca będzie przebywał w zacisznej przestrzeni w domu (np. w swoim pokoju), podczas gdy wywiady bezpośrednie $\mathrm{w}$ mieszkaniu badanego często odbywają się $\mathrm{w}$ przestrzeni łatwo dostępnej dla wszystkich domowników (salon), a przez to bardziej narażonej na obecność osób trzecich (Weller 2015).

Warto zaznaczyć, że analogiczne trudności występują także przy wywiadzie telefonicznym. W obu przypadkach brak wizualnych wskazówek dotyczących wieku, płci, pochodzenia etnicznego i innych cech można jednak także interpretować jako zaletę, ponieważ pozwala to ograniczyć efekt ankietera podczas wywiadu (Deakin, Wakefield 2014).
Inne ograniczenia wiążą się z sytuacją, gdy wywiad przez Skype'a jest przeprowadzany z użyciem kamery. Pozwala ona co prawda na obserwację gestów niewerbalnych, ale tylko częściowo, w zależności od ostrości i zasięgu kamery internetowej oraz rodzaju używanego urządzenia (Weller 2015). Nawet zastosowanie w programie Skype przekazu w jakości high definition (HD) nie gwarantuje tego, że uda się dokładnie zaobserwować niewerbalne reakcje rozmówcy, ponieważ może to uniemożliwić słaba przepustowość łącza, niewłaściwe oświetlenie czy zła jakość kamery wideo uczestnika (Lobe i in. 2020). Szczególnie mylące są sytuacje wynikające z niskiej jakości połączenia internetowego, gdy wideo jest opóźnione w stosunku do mowy uczestników (Whale 2017). Z kolei jeśli rozmówca trzyma w dłoni telefon czy podtrzymuje laptopa, ma zdecydowanie zawężone możliwości gestykulacji (Weller 2015). Poważnym ograniczeniem jest także to, że podczas wywiadów wideo przez Skype’a zazwyczaj widoczna jest jedynie górna część ciała (przy wywiadach z użyciem laptopów i komputerów), a nawet jedynie głowa rozmówcy (w przypadku smartfonów; Weller 2015). Nie jest więc możliwe, by - tak jak podczas wywiadu twarzą w twarz - obserwować niewerbalne reakcje całego ciała rozmówcy (Janghorban i in 2014; Lo Iacono i in 2016; Seitz 2016; Whale 2017). Perspektywa „gadających głów” (talking heads; Christian Licoppe, Julien Morel 2012 za Weller 2015) jest krytykowana za sztuczność, jednakże zdaniem niektórych badaczy takie usytuowanie sprawia, że interakcja jest bardziej intymna. Badacz i rozmówca, widząc na ekranie głównie swoje twarze ${ }^{9}$, odnoszą

\footnotetext{
${ }^{9} \mathrm{Na}$ interesujący wątek zwrócili uwagę Bertrand i Bourdeau (2010), których zaskoczyło to, że podczas wywiadów online przez znaczną część czasu patrzyli na swoje twarze zamiast na rozmówców. Związane to było z potrzebą kontroli własnej komunikacji niewerbalnej i wrażenia wywoływanego na rozmówcy. Możliwość autoobserwcji może być więc źródłem rozproszenia uwagi badacza, które powinno być przez niego kontrolowane (Bertrand, Bourdeau 2010).
} 
wrażenie, że są bliżej siebie, niż gdyby kamera obejmowała większą część ich sylwetki. Dzięki temu interakcja online w większym stopniu przypomina Goffmanowskie spotkanie twarzą w twarz (Weller 2015).

Trzeba jednak zaznaczyć, że bezpośredni kontakt wzrokowy w wywiadach online jest utrudniony ze względu na ograniczenia technologiczne. Ponieważ kamera umiejscowiona jest na krawędzi ekranu, aby sprawiać wrażenie, że patrzy się w oczy rozmówcy, należałoby patrzeć nie na osobę (w centrum ekranu), a w kamerę, co z kolei jest niekomfortowe (Bertrand, Bourdeau 2010; Lo Iacono i in. 2016; Adams-Hutcheson, Longhurst 2017; Krouwel i in. 2019). Niektórzy badacze uważaja, że niemożność patrzenia w oczy rozmówcy zakłóca proces budowania zaufania (Seitz 2016). Jednakże część uczestników wywiadów online postrzega tę cechę jako zaletę, ponieważ pomaga im to się otworzyć (Lo Iacono i in. 2016). Jak zauważają Lo Iacono, Symonds i Brown (2016), w realizowanych przez nich wywiadach online żaden z rozmówców (niezależnie od tego, czy przed wywiadem spotkał się badaczem offline, czy też nie) nie zgłaszał jakiegokolwiek kłopotu związanego z nawiązywaniem kontaktu wzrokowego. Przyznają jednak, że większość z nich używała Skype'a wcześniej i przywykła do tego rodzaju interakcji.

Podsumowując wątek budowania relacji badaczbadany w wywiadach przez Skype'a, można zauważyć, że to, czy rozmówca będzie preferował spotkanie twarzą w twarz, podczas którego zaangażowane są wszystkie zmysły, czy też odnajdzie się bez problemu w wywiadzie online, zależy od wielu czynników. Wywiad online niekoniecznie oznacza, że ustanowienie i utrzymanie relacji będzie trudniejsze. Wręcz odwrotnie, fizyczna separacja między badaczem a uczestnikiem może ją ułatwić (Wel- ler 2017). Nawiązanie relacji online może być jednak problemem podczas rozmowy z osobą, która jest bardziej powściągliwa lub mniej responsywna (Deakin, Wakefield 2014). Dla niektórych rozmówców warunkiem zbudowania zaufania jest spotkanie się z badaczem we wspólnej, fizycznej przestrzeni (Bertrand, Bourdeau 2010). Z tego względu niektórzy autorzy proponują, aby zorganizować spotkanie zapoznawcze offline przed właściwym wywiadem realizowanym przez Skype'a. Jeśli nie jest to możliwe, badacze zalecają kilkukrotną wymianę e-maili przed wywiadem, co może wzmocnić relację z badanymi i zmniejszyć ryzyko, że ostatecznie nie pojawi się on na wywiadzie (Deakin, Wakefiled 2014; Cin i in. 2016; Seitz 2016). Jak zauważają Deakin i Wakefield (2014), zastosowanie wywiadów poprzez Skypéa często skłania więc badacza do podjęcia dodatkowych starań $\mathrm{w}$ obszarze budowania relacji z rozmówca, które niekoniecznie podjąłby w wywiadzie bezpośrednim.

\section{Wyzwania etyczne}

Kolejnym źródłem wątpliwości dotyczącym prowadzenia wywiadów poprzez Skype'a jest etyka badań. Jak zauważają badacze stosujący ten rodzaj wywiadu, większość kwestii etycznych, jaka się z nim wiąże, jest analogiczna do tych pojawiających się w przypadku wywiadów twarzą w twarz (Janghorban i in. 2014; Lobe i in. 2020). Z tego względu skoncentruję się jedynie na tych wątkach, które są specyficzne dla wywiadów przez komunikator i są podnoszone przez jego krytyków ${ }^{10}$.

\footnotetext{
${ }^{10}$ Warto wspomnieć, że Internet jest często wykorzystywany w procesie rekrutacji uczestników i gromadzenia danych przez mniej doświadczonych badaczy (np. studentów piszących prace licencjackie czy magisterskie). W wielu przypadkach nie traktują oni z należytą uwagą kwestii etycznych, co nie tylko przekłada się na jakość ich badań i dobrostan osób badanych, ale także na złą opinię środowiska o badaniach online (Szpunar 2010; Stachura 2016).
} 
Często zgłaszaną wątpliwością wobec wywiadów poprzez Skype'a jest to, czy w ich przypadku możliwe jest poprawne przeprowadzenie procedury uzyskania świadomej zgody na udział w badaniu. Jednak, jak zauważają Sipes, Roberts i Mullan (2019), Skype pozwala na to, aby wcześniej przesłać uczestnikom wszelkie materiały informacyjne i formularz świadomej zgody, dzięki czemu mają oni więcej czasu niż w standardowym projekcie, aby się z nimi zapoznać. Komunikacja przed właściwym wywiadem (twarzą w twarz, za pomocą e-maila, telefonu czy Skype'a) pozwala na omówienie wszelkich wątpliwości rozmówcy dotyczących badania. Samą zaś zgodę można uzyskać na kilka sposobów: werbalnie, przed rozpoczęciem wywiadu; za pośrednictwem dedykowanej strony internetowej zawierającej niezbędne dokumenty, na której rozmówca udzieli zgody za pomocą swojej nazwy użytkownika w Skypie (Sipes i in. 2019); można także wysłać mailem wszelkie informacje, a następnie poprosić o przesłanie skanu wydrukowanego i podpisanego oświadczenia lub o maila zwrotnego z ich akceptacją (Lobe 2017). Możliwe są różne opcje, ale kluczowe jest to, aby szczegółowo wyjaśnić rozmówcy założenia projektu i odpowiedzieć na jego pytania i wątpliwości, co jak najbardziej jest możliwe z wykorzystaniem komunikacji zdalnej przed wywiadem. Należy zadbać o to, aby poświęcić na tę część odpowiednio dużo czasu (zob. Deakin, Wakefield 2014), co jednak jest dobrą praktyką w każdych badaniach, nie tylko online.

Choć badacze wskazują wiele zalet tego, że badany może sam wybrać miejsce, w którym przebywa podczas wywiadu, zauważają także związane z tym zagrożenia dla poufności. Uczestnicy mogą nie być do końca świadomi tego, co obejmuje kamera w ich urządzeniu (np. co odbija się w lustrze, co jest widoczne na drugim planie) i w rezultacie pokazać badaczowi coś, czego nie zamierzali. Zagrożenie to można jednak ograniczyć, doradzając badanym, na co powinni zwrócić uwagę, przygotowując miejsce wywiadu (Lo Iacono i in. 2016) lub też zasugerować im użycie opcji rozmycia tła (Lobe i in. 2020).

Bardzo ważną kwestią przy gromadzeniu danych online jest ich bezpieczeństwo. Należy je rozumieć na kilku poziomach. Poza działaniami, które badacze podejmują niezależnie od rodzaju wywiadu (zadbanie o to, by nie można było połączyć nagrań czy transkrypcji z danymi rozmówcy: adresem e-mail, telefonem, nazwą użytkownika w Skypie czy innymi informacjami, które mogłyby wskazać na jego tożsamość; bezpieczne przechowywanie nagrań i transkrypcji w szyfrowanych plikach [Lobe i in. 2020]), warto zabezpieczyć także konto w Skypie używane podczas badań. Jak radzą Lo Iacono, Symonds i Brown (2016), na potrzeby wywiadów warto założyć odrębne konto, a po zakończeniu projektu je zamknąć. Dzięki temu wszystkie dane dotyczące badanych zostaną usunięte.

Kolejną kwestią jest bezpieczeństwo danych podczas rozmowy, które w dużej mierze zależy od rozwiązań zastosowanych przez twórców danego oprogramowania (np. opcji zapraszania na spotkanie, blokowania nieuprawnionych uczestników, szyfrowania połączenia). Dostawcy oprogramowania nieustannie udoskonalają swoje usługi pod kontem ich bezpieczeństwa. Jednak, jak pokazuje przykład Zooma11, problemem (etycznym, ale

\footnotetext{
${ }^{11}$ Wiosną 2020 szerokim echem odbiły się problemy Zooma z włączaniem się osób postronnych na prywatne spotkania („Zoombombing”), a także niewystarczającym zabezpieczaniem danych i korzystaniem $\mathrm{z}$ chińskich serwerów (Lobe i in. 2020; https://www.pap.pl/pap-technologie/698263\%2Czoom-z-pozwem-za-niezgodne-z-prawda-twierdzenia-ntszyfrowania-rozmow.html [dostęp 16.05.2021]).
} 
i praktycznym) jest to, że w wywiadzie online interakcja odbywa się za pośrednictwem technologii będącej własnością osób trzecich (Lo Iacono i in. 2016; Jemielniak 2019). Także Skype gromadzi dane o użytkownikach, ich aktywności w sieci, lokalizacji. Co więcej, rozmowy mogą być monitorowane, a nawet nagrywane. Jest to zgodne $z$ regulaminem usługi, w którym dostawca zastrzegł sobie prawo do nagrywania i udostępniania treści przekazywanych podczas korzystania z programu w celu sprawdzenia, czy użytkownicy nie naruszają prywatności i praw autorskich osób trzecich ani nie udostępniają nielegalnych lub niewłaściwych treści (Lo Iacono i in. 2016; https://privacy.microsoft.com/ pl-pl/privacystatement/ [dostęp 23.11.2021]). Choć w przypadku większości tematów badawczych nie jest to być może dużym zagrożeniem, to należy brać to pod uwagę, jeśli tematem wywiadów są zachowania nielegalne, poza prawem (Sullivan 2012). Badacz powinien więc być świadomy rozwiązań zastosowanych w wybranym programie do wideokonferencji, aby wybrać najbezpieczniejszą opcje (zob. Jemielniak 2019), a także, jak sugerują Lo Iacono, Symonds i Brown (2016), przypomnieć/poinformować rozmówców przed wywiadem, że ich rozmowy mogą być udostępnione agencjom rządowym lub korporacjom. Alternatywą, którą można rozważyć, są programy open source, na przykład Jitsi Meet lub Jami. Sposobem na poradzenie sobie $\mathrm{z}$ tego typu problemami jest także zasugerowanie rozmówcom, by na potrzeby badań utworzyli konta w Skypie, posługując się fikcyjnymi danymi, co utrudni śledzenie ich aktywności (Sullivan 2012; Lo Iacono $i$ in. 2016). Jednocześnie zwraca to uwagę na kolejny dylemat, dotyczący weryfikacji tożsamości rozmówcy podczas wywiadów online, a przede wszystkim wątpliwości, czy prezentują oni badaczowi swoje wykreowane, czy też autentyczne Ja (autentyczniejsze niż w życiu prywatnym), które są w stanie ujawnić dopiero w bezpiecznej (postrzeganej jako anonimowa) przestrzeni Internetu (Janghorban i in. 2014). Kwestia ta była tematem wielu opracowań (zob. Kubczak 2005; Krejtz, Krejtz 2006; Mazurek 2006a; 2006b), dlatego też nie będę szczegółowo jej omawiać. Chciałabym tylko zaznaczyć za Brown (2018), że badacz nigdy nie może być pewien, jak uczciwi, otwarci i prawdomówni są jego rozmówcy, niezależnie od tego, czy wywiad prowadzony jest online czy bezpośrednio. $\mathrm{W}$ obu przypadkach badani mogą zachowywać się inaczej niż w prywatnych kontekstach, mogą też nieświadomie wprowadzać badacza w błąd. To, co może zrobić badacz, to być uważnym, refleksyjnym, zwracać uwagę na to, jak kontekst wywiadu może wpływać na zachowanie rozmówcy. Jak zauważa Brown (2018), w wywiadach zapośredniczonych przez Skype'a może to być jednak nieco trudniejsze, ponieważ badany w większym stopniu niż w wywiadach bezpośrednich kontroluje przekaz.

Warto zwrócić także uwagę na jeszcze jedno ryzyko etyczne związane z relacją badacza i badanego. Bertrand i Bourdeau (2010) zauważają, że większość ich rozmówców udzielała wywiadu, przebywając w swoim domu, przez co „uaktywniali” oni rodzinną ramę interpretacji tej sytuacji, podczas gdy dla badacza było to spotkanie służbowe, które jednak trudno było w taki sposób przeprowadzić, ponieważ niepostrzeżenie zmieniało się ono w przyjacielską rozmowę. Definiowanie sytuacji w kategoriach nieformalnego spotkania może zachęcać uczestników do ujawnienia podczas wywiadu online więcej, niż byliby skłonni powiedzieć podczas spotkania twarzą w twarz (Weller 2015; 2017; Jenner, Myers 2019). Rozmyciu może ulec rola badacza (Sipes i in. 2019), na przykład Brown (2018) podczas wywiadów przez Skypéa była oprowadzana po domu i przedstawiona mężowi rozmówczyni, choć sama 
nigdy by o to nie poprosiła, ponieważ czułaby, że przekracza granicę i nadużywa relacji z badanym. Choć $\mathrm{w}$ podobnych sytuacjach inicjatywa wychodziła ze strony rozmówców, którzy spontanicznie inicjowali takie interakcje i choć były one źródłem dodatkowych informacji dla badaczki, wiązały się one dla niej z dylematami etycznymi. Wbrew przekonaniom niektórych badaczy wywiad jakościowy online może więc wymagać od prowadzącego subtelnych działań, by nie wchodzić zbyt głęboko $\mathrm{w}$ świat badanych.

\section{Wywiady online i offline - porównanie}

We wcześniejszych sekcjach wskazałam, że wywiady realizowane za pośrednictwem Skype'a mają swoje mocne i słabe strony. Na koniec chciałabym przedstawić wnioski badaczy, którzy w swoich projektach stosowali równolegle wywiady internetowe i twarzą w twarz, a następnie dokonali porównania obu technik.

Jenner i Myers (2019) porównali wywiady zrealizowane na potrzeby ich projektów dotyczących studentów weteranów i ich ścieżek edukacyjnych (Jenner) oraz postaw i pragnień współczesnych amerykańskich kobiet w odniesieniu do macierzyństwa i coraz bardziej zróżnicowanych definicji rodziny (Myers). W obu projektach rozmówcy mogli udzielić wywiadu za pośrednictwem Skype'a lub twarzą w twarz. Z 90. zrealizowanych łącznie wywiadów 38 (42\%) zostało przeprowadzonych online. Porównując dane uzyskane za pomocą obu technik, Jenner i Myers koncentrowali się na jakości wywiadów oraz specyfice relacji badacz-badany. Jak zauważają, wbrew obawom opisywanym w literaturze naukowej (i wśród metodologów jakościowych), porównanie tych dwóch korpusów danych sugeruje, że, po pierwsze, w wywiadach zrealizowanych w przestrzeni prywatnej badanych (osobiście lub przez Skype’a) rozmówcy częściej dzielili się głęboko osobistymi doświadczeniami niż w wywiadach realizowanych $\mathrm{w}$ przestrzeni publicznej. Nie zaobserwowano natomiast różnic $\mathrm{w}$ tym względzie między rozmowami przez Skype'a a twarzą w twarz. Po drugie, rozmowa przez Skype’a (w porównaniu do wywiadów bezpośrednich) nie powodowała pogorszenia jakości ani zmiany charakteru relacji badacz-badany. Po trzecie, wywiady przez Skype'a nie różniły się długością trwania ani nie były częściej odwoływane lub przekładane niż wywiady bezpośrednie (Jenner, Myers 2019).

Przedstawiając bardziej szczegółowe wyniki porównań, Jenner i Myers zauważają, że wywiady prowadzone $\mathrm{w}$ przestrzeni prywatnej osobiście lub przez Skype’a były najbardziej do siebie podobne i przewyższały jakością wywiady zrealizowane twarzą $\mathrm{w}$ twarz $\mathrm{w}$ przestrzeni publicznej. Zdaniem autorów sugeruje to, że „prywatność”, a nie fakt zapośredniczenia komunikacji ma największe znaczenie dla uzyskania wysokiej jakości danych. W badaniach obu autorów wywiady zrealizowane za pośrednictwem Skype’a były dłuższe i rzadziej przekładane/odwoływane w porównaniu z wywiadami realizowanymi twarzą $\mathrm{w}$ twarz $\mathrm{w}$ miejscach publicznych. W obu próbach badawczych wywiady realizowane $\mathrm{w}$ miejscach publicznych były najkrótsze, czas trwania wywiadów twarzą w twarz i przez Skype'a zrealizowanych w przestrzeniach prywatnych był porównywalny, zaś najdłuższy wywiad w każdym badaniu odbywał się przez Skype’a (w przypadku badań dotyczących macierzyństwa było to 212 minut, zaś studentów weteranów - 94 minuty). Poza tym uczestnicy byli bardziej skłonni do dzielenia się negatywnymi uczuciami, osądami i potencjalnie stygmatyzującymi informacjami, gdy wywiad był prowadzony w przestrzeni 
prywatnej (bezpośrednio lub przez Skype'a), podczas gdy wywiady twarzą $\mathrm{w}$ twarz $\mathrm{w}$ miejscach publicznych były najbardziej naznaczone polityczną poprawnością (dotyczyło to zwłaszcza wątków samotnego macierzyństwa, alternatywnych form życia rodzinnego, traum wojennych, jakości usług dla weteranów). W wywiadach zapośredniczonych przez Skype'a miały także miejsce sytuacje wyjątkowo pogłębionych, osobistych wyznań rozmówców (exceptional disclosures). Podsumowując swoje doświadczenia, Jenner i Myers stwierdzają, że wywiad zapośredniczony przez Skype'a nie wiąże się z ryzykiem zaburzenia relacji badacza $\mathrm{z}$ badanymi i obniżenia jakości danych.

Do podobnych wniosków doszli także Lo Iacono, Symonds i Brown (2016), analizując wywiady dotyczące egipskiego tańca raqs sharqi jako formy dziedzictwa kulturowego (sześć z dziesięciu wywiadów zrealizowano przez Skype'a) oraz poznawczych i cielesnych procesów związanych z doświadczeniem odnajdywania drogi podczas podróżowania (14 z 22 wywiadów przeprowadzono przez Skypea). W ich ocenie dane zgromadzone w wywiadach zapośredniczonych były tak samo dobre jak w wywiadach bezpośrednich, a w niektórych przypadkach nawet lepsze, ponieważ rozmówcy, przebywając w swoich domach, mniej kontrolowali czas spotkania i mieli tendencję do tego, by mówić dłużej i więcej.

Do nieco innych wniosków doszli Krouwel, Jolly i Greenfield (2019), analizując 16 wywiadów z osobami cierpiącymi na zespół jelita drażliwego, z których połowę przeprowadzonobezpośrednio, połowę przez wideokonferencję na podstawie tego samego przewodnika do wywiadu. Badacze porównywali długość (czas trwania i liczbę słów) wywiadów, a $\mathrm{w}$ ich ramach wypowiedzi badacza i badanych, liczbę wygenerowanych w analizie wątków i kodów oraz liczbę zdań, na których bazowały kody. Na tej podstawie autorzy stwierdzili, że wywiady bezpośrednie były o 33\% dłuższe i miały o 14,6\% więcej słów niż wywiady online. Jednakże w wywiadach twarzą w twarz badacz wypowiadał o 30\% więcej słów niż w wywiadach zapośredniczonych (pytając, komentując, objaśniając itp.). Z kolei szybkość mówienia (speech rate), mierzona liczbą słów wypowiadanych na minutę, była o 16,2\% wyższa w wywiadach online. Jednocześnie liczba wygenerowanych kodów była niemal identyczna w obu typach wywiadów, jednak liczba zdań, na których się opierały, była wyższa w wywiadach bezpośrednich. Badacze nie do końca potrafią wyjaśnić opisane wyniki, wskazując na potrzebę dalszych badań i porównań. Zwracają także uwagę na to, że rozmówcy w obu typach wywiadów różnili się ze względu na wiek, płeć, pochodzenie etniczne i czas, jaki upłynął od momentu zdiagnozowania ich choroby, co mogło wpłynąć na otrzymane rezultaty. Jednocześnie badacze podkreślają, że z perspektywy jakościowej nie zauważyli żadnej znaczącej różnicy między przebiegiem wywiadów bezpośrednich i zapośredniczonych, także pod względem relacji z badanymi.

Porównań wywiadów online i twarzą w twarz dokonały także Deakin i Wakefield (2014) na podstawie danych zebranych w swoich dwóch projektach badawczych dotyczących sieci akademickich tworzonych w celu uczenia się i nauczania oraz mobilności studentów w zakresie praktyk zawodowych w Europie. Ze względu na rozproszenie geograficzne badanych populacji 56\% wywiadów badaczki przeprowadziły za pośrednictwem Skype'a (odpowiednio 25 z 40 wywiadów w pierwszym projekcie i 20 wywiadów z 40 zrealizowanych w drugim projekcie). Omawiając wyniki porównania obu technik, Deakin i Wakefield zauważają, że jakość odpo- 
wiedzi w wywiadach zapośredniczonych była taka sama jak tych w wywiadach tradycyjnych. Jednak w wywiadach za pośrednictwem Skype'a rozmówcy chętniej i szerzej odpowiadali na pytania, a relacja z badaczem była nawiązywana szybciej niż w wielu wywiadach bezpośrednich. Zdaniem badaczek trudności w nawiązaniu relacji badacz-badany poprzez Skype'a mogą wystąpić tylko, jeśli rozmówca jest bardzo powściągliwy lub mniej responsywny. Jednocześnie w obu projektach wywiady zapośredniczone częściej były przekładane i niezrealizowane niż wywiady twarzą w twarz. O ile wszyscy badani w wywiadach bezpośrednich stawili się na spotkanie, 8 osób (z 45), które umówiły się na rozmowę poprzez Skype'a, nie połączyło się w umówionym terminie. Pięć z tych wywiadów udało się zrealizować $\mathrm{w}$ innym terminie. Jak zauważają badaczki, choć ich próby badawcze były niewielkie, być może istnieje większe ryzyko tego, że w wywiadach przez Skype'a badani nie pojawią się na spotkaniu (zwłaszcza, jeśli nie znają badacza), niż ma to miejsce w wywiadach bezpośrednich (Deakin, Wakefield 2014).

Podsumowując refleksje badaczy, którzy stosowali w swoich projektach zarówno wywiady zapośredniczone, jak i bezpośrednie, można zauważyć, że jakość danych uzyskiwanych w wywiadach online jest wysoka i nie odbiega od jakości danych gromadzonych w wywiadach twarzą w twarz, a w niektórych przypadkach ją przewyższa. Jednocześnie rozbieżności w ocenie niektórych wymiarów (długości trwania, liczby słów, częstości odwoływania wywiadów) mogą wskazywać na to, o czym wspominałam we wcześniejszej części artykułu, że niektórzy badani czują się w tego typu wywiadach bardziej komfortowo niż inni, a także niektóre tematy mogą lepiej pasować do rozmowy online. Niezwykle interesujące są dla mnie obserwacje Jenner i Myersa (2019) dotyczące wpływu przestrzeni (publicz- nej, prywatnej) na treść wywiadu twarzą w twarz. Może być to ciekawy punkt wyjścia do rozwijania refleksji nad tradycyjnymi wywiadami w porównaniu do wywiadów online.

\section{Podsumowanie}

Omówione powyżej kwestie wskazują, że wywiady online mogą przynieść korzyści zarówno badaczom, jak i uczestnikom, szczególnie jeśli:

- badacz i potencjalni rozmówcy mają dostęp do sprzętu oraz technologii umożliwiających komunikowanie się audio-wideo online, są z nimi zaznajomieni lub co najmniej są otwarci na to, by się ich nauczyć;

- mogą mieć trudności z udzieleniem wywiadu bezpośredniego ze względu na koszty i czas podróży, doświadczane choroby i niepełnosprawności;

- ze względu na indywidualne preferencje, temat badawczy (związany z intymnymi, stygmatyzującymi kwestiami) i/lub sytuację zewnętrzną (np. obostrzenia związane $\mathrm{z}$ pandemią COVID-19) preferują kontakt dający większe poczucie bezpieczeństwa i anonimowości;

- badaczowi zależy na tym, by możliwe było elastyczne dopasowywanie terminu, czasu trwania, miejsca wywiadu do możliwości ipotrzeb badanych (i własnych);

- badaczowi zależy na zbudowaniu dobrej relacji z badanymi, ale w nieformalnej atmosferze, której może brakować podczas wywiadów bezpośrednich $\mathrm{w}$ przestrzeniach instytucjonalnych wskazanych przez badacza (Weller 2015) lub też która może wiązać się ze zbyt dużą in- 
gerencją w przestrzeń badanego (np. przy fizycznej obecności w jego domu; Brown 2018).

To, co szczególnie warte jest uwagi w wywiadach zapośredniczonych przez Skype'a, to elastyczność, wszechstronność i wygoda, jaką zapewniają badaczowi i rozmówcom (Hanna 2012; Weller 2015). Technika ta jest także bardzo obiecująca, jeśli weźmiemy pod uwagę wymiar etyczny (Glassmeyer, Dibbs 2012). Daje ona szansę na poznanie perspektywy osób, które z różnych powodów nie brały(by) udziału w wywiadach bezpośrednich. Choć oczywiście należy pamiętać, że wywiady online nie są panaceum na istniejące nierówności cyfrowe oraz społeczne i trudno oczekiwać, że ich zastosowanie będzie wolne od ograniczeń wynikających z podziałów klasowych, płciowych czy rasowych (Murthy 2008).

Z mojej perspektywy decyzja o prowadzeniu wywiadów online jest także związana z wizją badań, jaką podziela badacz i jego przekonaniami na temat roli badacza, kontroli i władzy w badaniu. W przypadku wywiadów swobodnych przez komunikator znaczna część kontroli jest oddana badanym - to oni wybierają miejsce, w którym udzielą wywiadu, decyduja, na ile pokażą badaczowi siebie i swoje otoczenie (dosłownie i w przenośni), mają większy wpływ na termin oraz czas trwania wywiadu. Mają także większą kontrolę nad procesem nagrywania i na równi z badaczem posiadają dostęp do nagrania. Technika ta posiada więc potencjał demokratyzowania relacji badacz-badany (Meho 2006; Deakin, Wakefield 2014; Cin i in. 2016; Lo Iacono i in. 2016), co może być postrzegane przez badacza jako wartość sama w sobie lub też zagrożenie.

W mojej ocenie korzystnym rozwiązaniem jest pozostawianie potencjalnym uczestnikom decyzji o tym, jaki rodzaj wywiadu preferuja. Wymaga to zaufania do rozmówców, że wybiorą sposób, który będzie dla nich najlepszy i pozwoli im poczuć się komfortowo na tyle, by udzielić wysokiej jakości wywiadu (w konsekwencji, będzie więc to także najlepszy wybór z perspektywy badacza). To, czy będzie to wywiad bezpośredni, czy też zapośredniczony na przykład przez Skype'a wpłynie rzecz jasna na sposób nawiązywania relacji i przebieg spotkania. Nie oznacza to jednak, że wywiad zapośredniczony będzie gorszy. Może się natomiast zdarzyć, że wywieranie presji na rozmówcę, by zgodził się na inny (preferowany przez badacza) sposób przeprowadzenia wywiadu zaowocuje niższej jakości danymi lub rezygnacją z udziału w projekcie.

Jednak, jak wskazywałam w artykule, wywiad zapośredniczony przez Skype'a nie jest pozbawiony wad i ograniczeń. Obszary, które mogą stanowić wyzwanie dla badacza i badanych, to:

- techniczne kłopoty ze sprzętem, mikrofonem, jakością połączenia internetowego;

- wątpliwości dotyczące bezpieczeństwa danych uzyskiwanych za pośrednictwem trzeciej strony (firmy dostarczającej oprogramowanie);

- ryzyko nadmiernej otwartości badanego;

- wątpliwości dotyczące autentyczności versus kreowania się rozmówców podczas rozmowy online (Brown 2018).

Dodatkowe wątpliwości wobec wywiadów online pojawiły się wraz z pandemią COVID-19 i związanym z nią (szczególnie w okresie kwarantanny narodowej, edukacji i pracy zdalnej) przeniesieniem większości interakcji do Internetu. Nasiliły się wtedy obawy przed „onlinizacją" badań i rzeczywistości społecznej w ogóle (the onlineification of everything; Braun i in. 2020; Nind i in. 2021). Z drugiej strony nawet sceptycz- 
ne wobec wywiadów online brytyjskie Oral History Society zauważa, że nagrywanie historii mówionych online może stać się wkrótce „nową normą” (Polskie Towarzystwo Historii Mówionej 2020; Morgan i in. 2021). Postępująca wirtualizacja kontaktów zarówno w wymiarze prywatnym, jak i zawodowym sprawia, że coraz częściej kontaktujemy się z innymi ludźmi za pomocą technologii, przede wszystkim Internetu i telefonii komórkowej. Zamiast więc rozważać w odniesieniu do wywiadów online i offline, który z nich jest lepszy czy bardziej naturalny, warto pamiętać, że choć niektóre sposoby komunikowania się mogą wydawać się bardziej naturalne niż inne, to wszystkie interakcje są ustrukturyzowane przez zinternalizowane wzory kulturowe (Adams-Hutcheson, Longhurst 2017). W tym sensie komunikacja zawsze jest zapośredniczona, niezależnie od tego, czy odbywa się twarzą w twarz, czy też rozmówcy znajdują się po dwóch stronach ekranu.

\section{Bibliografia}

Adams-Hutcheson Gail, Longhurst Robyn (2017) At least in person there would have been a cup of tea': interviewing via Skype. „Area”, vol. 49, no. 2, s. 148-155.

Archibald Mandy M. i in. (2019) Using zoom videoconferencing for qualitative data collection: perceptions and experiences of researchers and participants. „International Journal of Qualitative Methods", vol. 18, s. 1-8.

Batorski Dominik (2005) Internet a nierówności społeczne. „Studia Socjologiczne", t. 177, nr 2, s. 107-131.

Batorski Dominik (2009) Wykluczenie cyfrowe w Polsce. „Studia Biura Analiz Sejmowych", t. 3, nr 19, s. 223-249.

Batorski Dominik, Olcoń-Kubicka Marta (2006) Prowadzenie badań przez Internet-podstawowe zagadnienia metodologiczne. „Studia Socjologiczne", t. 3, nr 182, s. 99-132.
Wywiad poprzez Skype'a jest więc kolejnym narzędziem w skrzynce narzędziowej badacza jakościowego (Bouchard 2016), które może być bardzo przydatne we współczesnej rzeczywistości społecznej. I choć stosujący go badacze nie są zgodni, czy to technika, którą można wykorzystać jedynie jako uzupełnienie tradycyjnych technik (np. wywiadów swobodnych, fokusowych) w ramach jednego projektu badawczego (Lo Iacono i in. 2016; Archibald i in. 2019; Krouwel i in. 2019), drugorzędna technika wybierana, gdy nie jest możliwe przeprowadzenie wywiadu twarzą w twarz, czy też pełnoprawny wywiad, dzięki któremu można generować dane tak wiarygodne i pogłębione jak te uzyskiwane podczas spotkań twarzą w twarz (Deakin, Wakefield 2014; Weller 2017), warto rozważyć jej zastosowanie w projekcie. Tym bardziej, że - porównując go z innymi technikami wywiadów na odległość (telefonicznym, mailowym) - daje badaczowi i rozmówcom wiele nowych możliwości.

Beneito-Montagut Roser (2011) Ethnography goes online: towards a user-centred methodology to research interpersonal communication on the internet. "Qualitative Research", vol. 11, no. 6, s. 716-735.

Bertrand Catherine, Bourdeau Laurent (2010) Research interviews by Skype: A new data collection method [w:] Jose Esteves, ed., Proceedings from the 9th European Conference on Research Methods. Spain: IE Business School, s. 70-79.

Bielska Beata, Kurek-Ochmańska Olga, Łuczaj Kamil (2021) Jak badać wysoko wykwalifikowanych migrantów? Praktyczne wskazówki metodologiczne. „Studia Migracyjne”, t. 79, s. 125-148. DOI: 10.4467/25444972SMPP.21.006.13318 (http://www.ejournals.eu/ Studia-Migracyjne/) [dostęp 23.11.2021].

Bouchard Karen L. (2016) Anonymity as a Double-Edge Sword: Reflecting on the Implications of Online Qualitative Research in Studying Sensitive Topics. „The Qualitative Report”, vol. 21, no. 1, s. 59-67. 
Braun Robert i in. (2020) COVID-19 and the onlineification of research: kick-starting a dialogue on Responsible online Research and Innovation (RoRI). „Journal of Responsible Innovation”. DOI: 10.1080/23299460.2020.1789387 (https://www.tandfonline.com/ toc/tjri20/current) [dostęp 23.11.2021].

Brown Nicole (2018) Video-Conference Interviews: Ethical and Methodological Concerns in the Context of Health Research. SAGE Research Methods Cases. DOI: https://www.doi. org/10.4135/9781526441812 [dostęp 23.11.2021].

Cin Melis F. i in. (2016) Transnational online research: Recognising multiple contexts in Skype-to-phone interviews. "Qualitative Research". DOI: https://doi.org/10.1177/14687941211024824 [dostęp 23.11.2021].

Deakin Hannah, Wakefield Kelly (2014) Skype interviewing: Reflections of two PhD researchers. "Qualitative Research", vol. 14, no. 5, s. 603-616. DOI: https://journals.sagepub.com/ doi/10.1177/1468794113488126 [dostęp 23.11.2021].

Dyskusja. Badania społeczne i humanistyczne w czasach pandemiiaspekty etyczno-metodologiczne. Dyskusja podczas "Spotkań Badaczek” (2020) „Przegląd Socjologiczny”, t. 69, nr 3, s. 203-214. DOI: https://doi.org/10.26485/PS/2020/69.3/10 [dostęp 23.11.2021].

Foley Geraldine (2021) Video-based online interviews for palliative care research: A new normal in COVID-19? "Palliative Medicine", vol. 35, no. 3, s. 625-626. DOI: https://doi. org/10.1177/0269216321989571 [dostęp 23.11.2021].

Given Lisa M., Saumure Kristie (2015) Using Skype as a Research Tool: Lessons Learned from Qualitative Interviews with Distance Students in a Teacher Librarianship Program. (https://www.academia.edu/1774333/Using_Skype_as_a_Research_Tool_Lessons_Learned_from_Qualitative_Interviews_with_Distance_Students_in_a_Teacher-Librarianship_Program) [dostęp 27.04.2021].

Glaser Barney, Strauss Anselm L. (2009) Odkrywanie teorii ugruntowanej. Przełożył Marek Gorzko. Kraków: Zakład Wydawniczy Nomos.

Glassmeyer David M., Dibbs Rebecca-Anne (2012) Researching from a distance: Using live web conferencing to mediate data collection. „International Journal of Qualitative Methods”, vol. 11, no. 3, s. 292-302. DOI: https://doi.org/10.1177/160940691201100308 [dostęp 23.11.2021].

Goffman Erving (2000) Człowiek w teatrze życia codziennego. Przełożyli Helena Datner-Śpiewak, Paweł Śpiewak. Warszawa: Wydawnictwo Naukowe PWN.
Goffman Erving (2011) Relacje w przestrzeni publicznej. Przełożyła Olga Siara. Warszawa: Wydawnictwo Naukowe PWN.

Grochalska Monika (2017) Rytuaty w zwiazku - dyskursywne konstruowanie intymności. „Dyskursy Młodych Andragogów”, t. 18, s. 331-345.

Hanna Paul (2012) Using internet technologies (such as Skype) as a research medium: A research note. "Qualitative Research", vol. 12 , no. 2 , s. 239-242. DOI: https://journals.sagepub.com/ doi/10.1177/1468794111426607 [dostęp 24.11.2021].

Horolets Anna (2016) Badacz jako gość. „Przegląd Socjologii Jakościowej", t. 12, nr 3, s. 54-69 (www.przegladsocjologiijakosciowej.org) [dostęp 24.11.2021].

Jakubowska Honorata (2016) Kontrolowanie formy ciężarnego ciała. "Acta Universitatis Lodziensis. Folia Sociologica", t. 58, s. 89-102.

Janghorban Roksana, Roudsari Latifnejad Robab, Taghipour Ali (2014) Skype interviewing: The new generation of online synchronous interview in qualitative research. „International Journal of Qualitative Studies on Health and Well-being", vol. 9, no. 1, s. 241-252. DOI: 10.3402/qhw.v9.24152 [dostęp 24.11.2021].

Jemielniak Dariusz (2013) Życie wirtualnych dzikich. Netnografia Wikipedii, największego projektu wspóttworzonego przez ludzi. Warszawa: Wydawnictwo poltext.

Jemielniak Dariusz (2019) Socjologia Internetu. Warszawa: Wydawnictwo Naukowe Scholar.

Jenkins Suzanne (2010) New Technologies, New Territories: Using The Internet to Connect with Sex Workers and Sex Industry Organizers [w:] Kate Hardy, Sarah Kingston, Teela Sanders, eds., New Sociologies of Sex Work. Farnham UK, Burlington VT, USA: Ashgate Publishing, s. 91-108.

Jenner Brandy M., Myers Kit C. (2019) Intimacy, rapport, and exceptional disclosure: a comparison of in-person and mediated interview contexts. „International Journal of Social Research Methodology", vol. 22, no. 2, s. 165-177.

Krauz Wika (2020) Wyimki z dziennika terenowego. „Zeszyty Naukowe Uniwersytetu Jagiellońskiego Prace Etnograficzne”, t. 48, z. 1, s. 111-114. DOI: 10.4467/22999558.PE.20.008.12633 [dostęp 24.11.2021].

Krejtz Krzysztof, Krejtz Izabela (2006) Ja w sieci - sieć we mnie. Zależności pomiędzy doświadczeniami relacji w internecie a reprezentacja obrazu siebie [w:] Dominik Batorski, Mirosława Marody, 
Andrzej Nowak, red., Społeczna przestrzeń Internetu. Warszawa: Wydawnictwo SWPS, s. 91-112.

Krouwel Matthew, Jolly Kate, Greenfield Sheila (2019) Comparing Skype (video calling) and in-person qualitative interview modes in a study of people with irritable bowel syndrome-an exploratory comparative analysis. "BMC Medical Research Methodology”, vol. 19, no. (1), s. 1-9.

Kubczak Anna (2005) Konstruowanie tożsamości w Internecie [w:] Elżbieta Hałas, Krzysztof Konecki, red., Konstruowanie jaźni $i$ tożsamości. Europejskie warianty symbolicznego interakcjonizmu. Warszawa: Wydawnictwo Naukowe Scholar, s. 359-378.

Lo Iacono Valeria, Symonds Paul, Brown David H. K. (2016) Skype as a Tool for Qualitative Research Interviews. "Sociological Research Online", vol. 21, no. 2, s. 103-117.

Lobe Bojana (2017) Best practices for synchronous online focus groups [w:] Rosaline S. Barbour, David. L. Morgan, eds., A new era in focus group research: Challenges, innovation and practice. London: Palgrave Macmillan, s. 227-250.

Lobe Bojana, Morgan David, Hoffman Kim A. (2020) Qualitative data collection in an era of social distancing. „International Journal of Qualitative Methods", vol. 19, s. 1-8. DOI: 1609406920937875 [dostęp 24.11.2021].

Mazurek Paweł (2006a) Anatomia internetowej anonimowości [w:] Dominik Batorski, Mirosława Marody, Andrzej Nowak, red., Społeczna przestrzeń Internetu. Warszawa: Wydawnictwo SWPS, s. 79-90.

Mazurek Paweł (2006b) Internet i tożsamość [w:] Dominik Batorski, Mirosława Marody, Andrzej Nowak, red., Społeczna przestrzeń Internetu. Warszawa: Wydawnictwo SWPS, s. 112-132.

Meho Lokman I. (2006) E-Mail Interviewing in Qualitative Research: A Methodological Discussion. "Journal of the American Society for Information Science and Technology", vol. 57, no. 10, s. 1284-1295.

Miner Michael H. i in. (2011) Conducting Internet Research With the Transgender Population: Reaching Broad Samples and Collecting Valid Data. „Social Science Computer Review”, vol. 30, no. 2, s. 202-211.

Morgan Charlie i in. (2021) Advice on oral history interviewing during the Covid-19 pandemic. Oral History Society. (https://www. ohs.org.uk/advice/covid-19) [dostęp 16.02.2021].

Murthy Dhiraj (2008) Digital Ethnography: An Examination of the Use of New Technologies for Social Research. "Sociology”, vol. 42, no. 5, s. 837-855.
Nehls Kimberly, Smith Brandy D., Schneider Holly A. (2015) Video-conferencing interviews in qualitative research [w:] Shalin Hai-Jew, ed., Enhancing qualitative and mixed methods research with technology. Hershey, PA: IGI Global, s. 140-157.

Nind Melanie, Coverdale Andy, Meckin Robert (2021) Changing social research practices in the context of Covid-19: rapid evidence review. „Working paper NCRM”. (http://eprints.ncrm.ac.uk/4398/) [dostęp 18.03.2021].

Palęcka Alicja (2021) "Spokojnie, jestem grzeczny”. Molestowanie seksualne jako strategia uczestników badania. "Przegląd Socjologii Jakościowej", t. 17, nr 2, s. 44-60. DOI: https://doi. org/10.18778/1733-8069.17.2.03 [dostęp 24.11.2021].

Peach Emily (2021) Using Skype to research literacy practices: providing opportunities for participants with mental health conditions to share their experiences. „Literacy”, vol. 55, no. 3, s. 201-209. DOI: https://doi.org/10.1111/lit.12248 [dostęp 24.11.2021].

Polskie Towarzystwo Historii Mówionej (2020) Historia mówiona a epidemia COVID-19. Rekomendacje Polskiego Towarzystwa Historii Mówionej. „Wrocławski Rocznik Historii Mówionej”, t. 10, s. 246-256.

Rettie Ruth (2009) Mobile phone communication: extending Goffman to mediated interaction. "Sociology”, vol. 43, no. 3, s. 421-438.

Rostocki Andrzej W. (1999) Socjologia a prywatność. „Przegląd Socjologiczny", t. 48, nr 1, s. 23-41.

Seitz Sally (2016) Pixilated partnerships, overcoming obstacles in qualitative interviews via Skype: A research note. "Qualitative Research", vol. 16, no. 2, s. 229-235.

Sipes Jessica B., Roberts Lynne D., Mullan Barbara (2019) Voice-only Skype for use in researching sensitive topics: a research note. "Qualitative Research in Psychology", s. 1-17. DOI: 10.1080/14780887.2019.1577518 [dostęp 24.11.2021].

Siuda Piotr (2016a) Wprowadzenie. Przełamywanie metodologicznych podziałów w rozważaniach o internetowych metodach badawczych [w:] Piotr Siuda, red., Metody badań online. Gdańsk: Wydawnictwo Naukowe Katedra, s. 7-25.

Siuda Piotr, red., (2016b) Metody badań online. Gdańsk: Wydawnictwo Naukowe Katedra.

Stachura Krzysztof (2016) Problemy zapewniania jakości w badaniach online [w:] Piotr Siuda, red., Metody badań online. Gdańsk: Wydawnictwo Naukowe Katedra, s. 154-180. 
Stojkow Maria, Żuchowska Dorota (2014) W kierunku nowej tożsamości--osoby niepetnosprawne w drodze ku emancypacji. „Studia Socjologiczne", t. 2, s. 153-174.

Sullivan Jessica R. (2012) Skype: An Appropriate Method of Data Collection for Qualitative Interviews? „The Hilltop Review”, vol. 6, no. 1, article 10. (https://scholarworks.wmich.edu/hilltopreview/vol6/iss1/10) [dostęp 24.11.2021].

Szpunar Magdalena (2010) Internet w procesie realizacji badań. Torun: Wydawnictwo Adam Marszałek.

Ślęzak Izabela (2013) Nowe techniki, stare problemy? refleksje na temat badań społecznych realizowanych w środowisku osób świadczacych ustugi seksualne. "Przegląd Socjologiczny", t. 62, nr 1, s. 139-152.

Ślęzak Izabela (2018) Praca nad zaufaniem. Etyczne, praktyczne $i$ metodologiczne wyzwania w relacjach badacz-badani na przykładzie etnografii agencji towarzyskich. „Przegląd Socjologii Jakościowej", t. 14, nr 1, s. 138-162. DOI: https://doi.org/10.18778/17338069.14.1.07 [dostęp 24.11.2021].
Weinmann Tobias i in. (2012) Testing Skype as an interview method in epidemiologic research: response and feasibility. „International journal of public health", vol. 57, no. 6, s. 959-961.

Weller Susie (2015) The potentials and pitfalls of using Skype for qualitative (longitudinal) interviews. NCRM Working Paper (https://eprints.ncrm.ac.uk/id/eprint/3757/) [dostęp 29.04.2021].

Weller Susie (2017) Using internet video calls in qualitative (longitudinal) interviews: some implications for rapport. „International Journal of Social Research Methodology", vol. 20, no. 6, s. 613625, DOI: 10.1080/13645579.2016.1269505 [dostęp 24.11.2021].

Whale Katie (2017) The use of Skype and telephone interviews in sensitive qualitative research with young people: experiences from the ROCCA continence study. "Qualitative Methods in Psychology Bulletin", no. 2 https://research-information.bris.ac.uk/en/ publications/the-use-of-skype-and-telephone-interviews-insensitive-qualitativ [dostęp 6.04.2021].

Winzenburg Stephen (2012) How Skype is changing the interview process. „Chronicle of Higher Education”, vol. 58, no. 18, s. D9-D10.

\section{Cytowanie}

Ślęzak Izabela (2021) Zło konieczne, substytut, szansa - wykorzystanie komunikatora Skype w badaniach jakościowych. „Przegląd Socjologii Jakościowej”, t. 17, nr 4, s. 88-113 [dostęp dzień, miesiąc, rok]. Dostępny w Internecie: «www.przegladsocjologiijakosciowej.org〉. DOI: https://doi.org/10.18778/1733-8069.17.4.05

\section{A Necessary Evil, a Substitute, or an Opportunity? Using Skype in Qualitative Research}

Abstract: The paper aims to introduce the technique of unstructured online interviews in a unique form whereby the interviews are conducted via Skype. Although qualitative researchers are using this technique more and more often, it evokes mixed reactions - from being seen as an opportunity, an (in)valuable substitute for face-to-face interviewing, to being even considered a threat to research quality. Based on the relevant literature, I will discuss the characteristics of the Skype interview as well as its advantages and limitations from the perspectives of both the researcher and the research participants. I will further demonstrate how researchers who have used this type of interview dealt with the said limitations. The results of comparing online interviews with face-to-face interviews by researchers who have used both techniques will also be presented. The relationship between the researcher and the interviewee - and the ethical issues related to the implementation of Skype-mediated interviews - will be expounded in more detail. Finally, I will indicate the necessary conditions as to when conducting this type of interview turns out to be the most beneficial.

Keywords: qualitative interview via Skype, online interview, video-conferencing interview, unstructured interview, Internet 